Florida International University FIU Digital Commons

3-30-2004

\title{
Retail centers for community : addressing both pedestrian and car traffic
}

Luis Asturias

Florida International University

DOI: $10.25148 /$ etd.FI14032364

Follow this and additional works at: https://digitalcommons.fiu.edu/etd

Part of the Architecture Commons

\section{Recommended Citation}

Asturias, Luis, "Retail centers for community : addressing both pedestrian and car traffic" (2004). FIU Electronic Theses and Dissertations. 2063.

https://digitalcommons.fiu.edu/etd/2063

This work is brought to you for free and open access by the University Graduate School at FIU Digital Commons. It has been accepted for inclusion in FIU Electronic Theses and Dissertations by an authorized administrator of FIU Digital Commons. For more information, please contact dcc@fiu.edu. 


\section{FLORIDA INTERNATIONAL UNIVERSITY}

Miami, Florida

\section{RETAIL CENTERS FOR COMMUNITY: \\ ADDRESSING BOTH PEDESTRIAN AND CAR TRAFFIC}

A thesis submitted in partial fulfillment of the

requirements for the degree of

MASTER OF ARCHITECTURE

by

Luis Asturias

2004 
To: Dean Juan Antonio Bueno

School of Architecture

This thesis, written by Luis Asturias, and entitled Retail Centers for Community: Addressing both Pedestrian and Car Traffic, having been approved in respect to style and intellectual content, is referred to you for judgment.

We have read this thesis and recommend that it be approved.

Norman Blandon

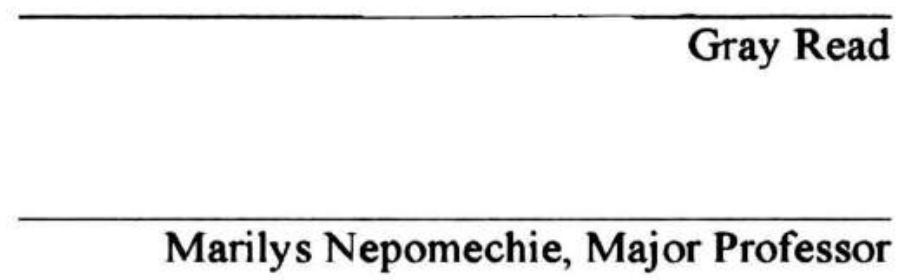

Date of Defense: March 30, 2004

The thesis of Luis Asturias is approved.

Dean Juan Antonio Bueno
School of Architecture

Florida International University, 2004 


\section{DEDICATION}

I dedicate this thesis to my wife, Elena and to my family. Their love and support have made this work possible. 


\section{ACKNOWLEDGMENTS}

I would like to thank the members of my committee for sharing their knowledge and for their support and guidance during my time in school and with this thesis process. 


\author{
ABSTRACT OF THE THESIS \\ RETAIL CENTERS FOR COMMUNITY: \\ ADDRESSING BOTH PEDESTRIAN AND CAR TRAFFIC \\ by \\ Luis Asturias \\ Florida International University, 2004 \\ Miami, Florida \\ Professor Marilys Nepomechie, Major Professor
}

The purpose of this thesis was to redesign a commercial center in Miami, Florida in a manner that incorporates the needs of pedestrians as well as the automobile.

In my research, I studied projects that had been successful at integrating cars in retail design. I applied the strategies learned from this research to the design of a center that creates a positive interaction of pedestrian and car traffic, addressing the needs of the surrounding community.

I designed a master plan that includes a mix of residential, retail, commercial and parking space. The parking is designed so that the retail center is not dominated by surface parking. Rather, the automobile is introduced into the different layers of the proposed buildings. The design focused on connecting pedestrian plazas and parking areas beneath them through the introduction of light and greenery. The findings show how a shopping center might transform the area around it by including spaces for residential, civic, cultural and social functions, as well as for the automotive infrastructure that make those functions possible. 


\section{TABLE OF CONTENTS}

CHAPTER

PAGE

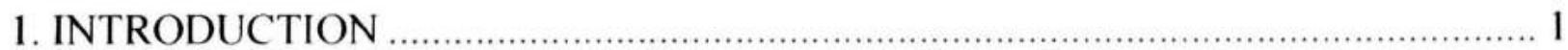

2. THE INFLUENCE OF THE CAR ON THE RETAIL ENVIRONMENT ………....... 2

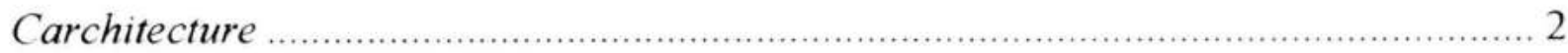

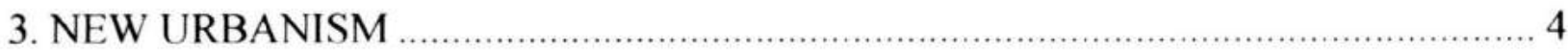

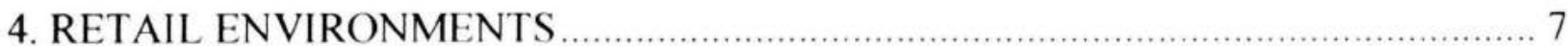

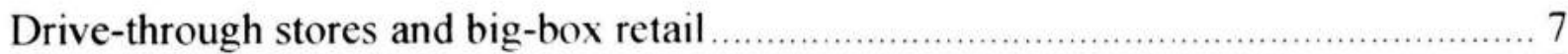

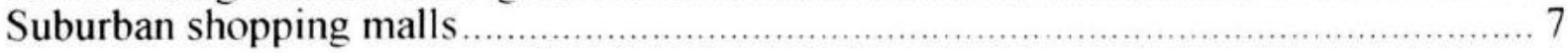

5. PEDESTRIANS

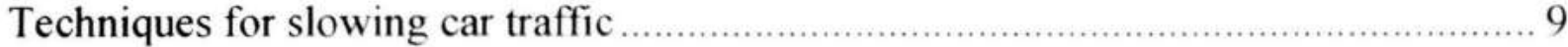

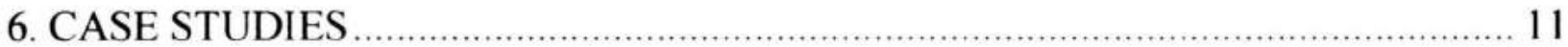

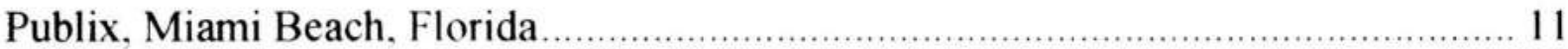

Uptown District, San Diego. California

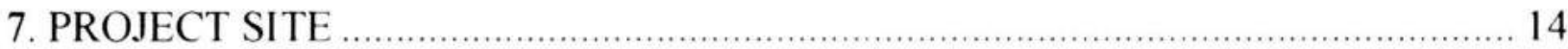

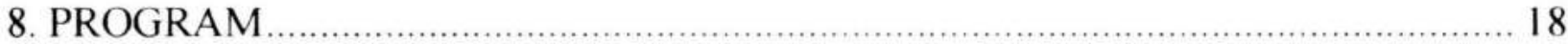

Master plan parking breakdown ……… 19

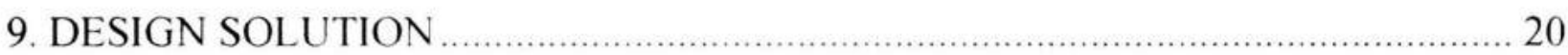

10. SUMMARY

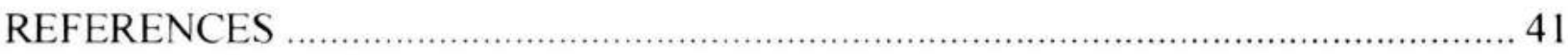




\section{LIST OF FIGURES}

FIGURE

PAGE

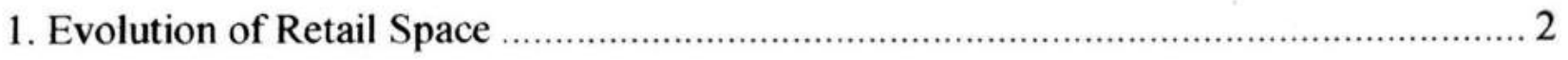

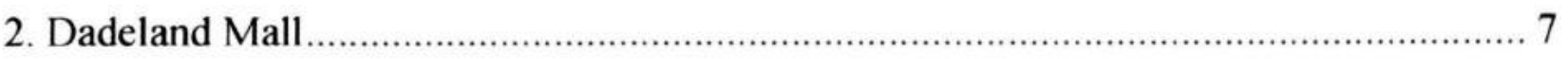

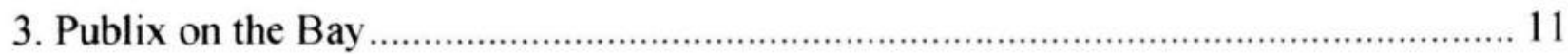

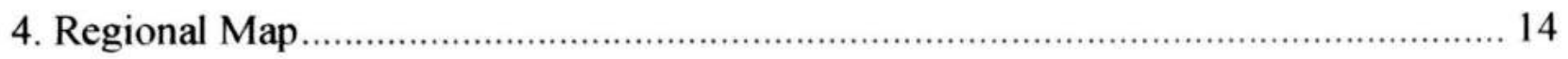

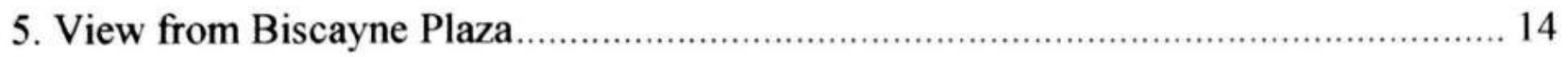

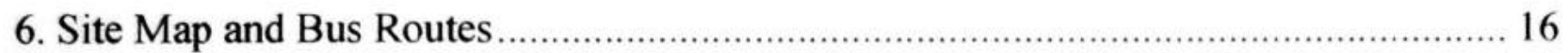

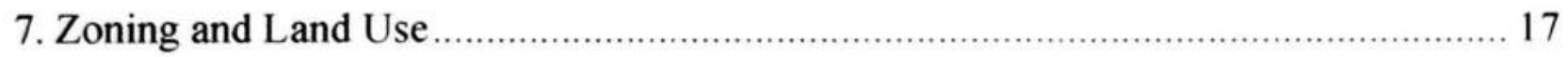

8. Strategy Diagrams

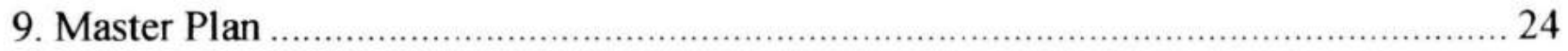

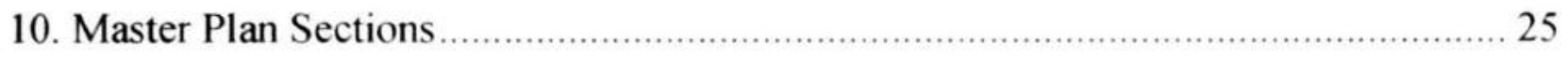

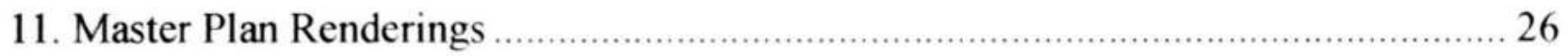

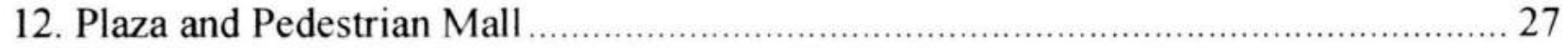

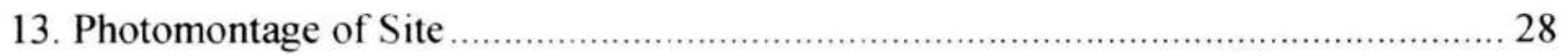

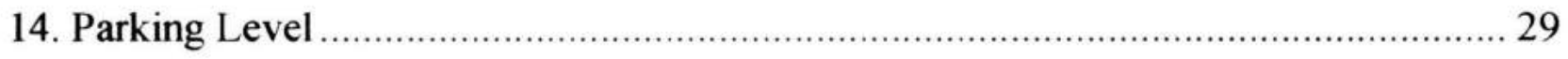

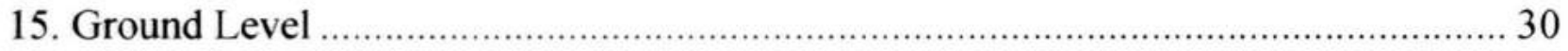

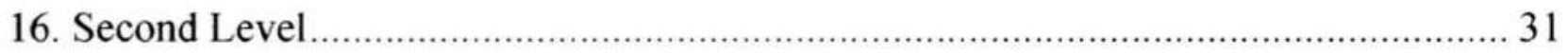

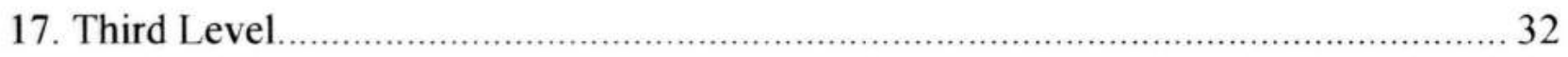

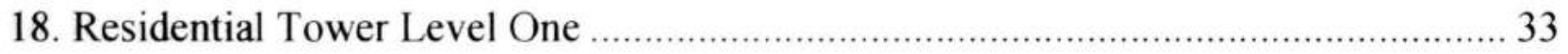

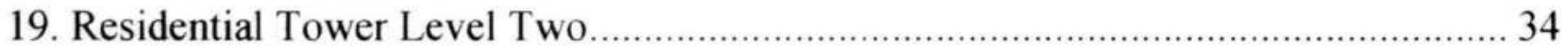

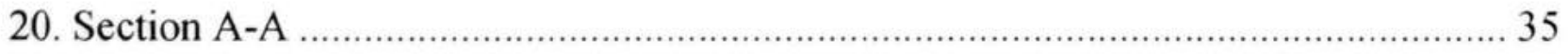

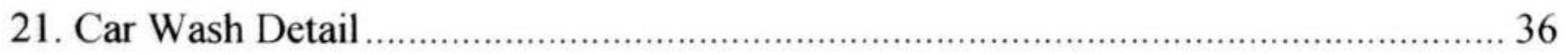


22. Plaza and Parking Below 37

23. Main Plaza Aerial View 38

24. Main Plaza Rendering 39 


\section{Chapter 1. Introduction}

This study focused on the relationship between pedestrian and automobile traffic in the city. This issue is particularly relevant in the design of commercial centers adjacent to residential neighborhoods. The project asked how retail centers can address both pedestrian and car traffic in a manner that strengthens pedestrian connections to residential neighborhoods while maintaining automotive connections to the city at large. Specifically, the project undertakes the redesign of a largely abandoned mid-century commercial center along a main traffic artery in the City of Miami in order to both create a center for the community in the surrounding residential area while also serving the larger region. The project investigated ways in which the shopping center might help to transform the area around it by including spaces for residential, civic, cultural, and social functions that address the needs of the community-as well as for the automotive infrastructure that make those functions possible. 
Chapter 2. The Influence of the Car on the Retail Environment

The design addressed parking needs and accessibility by car, which are some of the biggest considerations in retail design. Richard Longstreth explains, "As cars and parking became the primary components in the construction of new retail centers, they turned shopping from a "pedestrian activity" into a "park-n-shop" one." Leaders of the New Urbanism movement, Andrés Duany and Elizabeth Plater-Zyberk explain that retail and residential communities have become disconnected by the car as, "Automobile traffic and its landscape have become the central, unavoidable experience of the public realm." The project addressed these issues by focusing on the different spatial requirements of cars and pedestrians, and develops buildings and public spaces that accommodate both.

Jonathan Bell, the author of Carchitecture explains that if designers focus only on pedestrian traffic and design spaces without considering cars, the end result is isolation since the social function of the car is

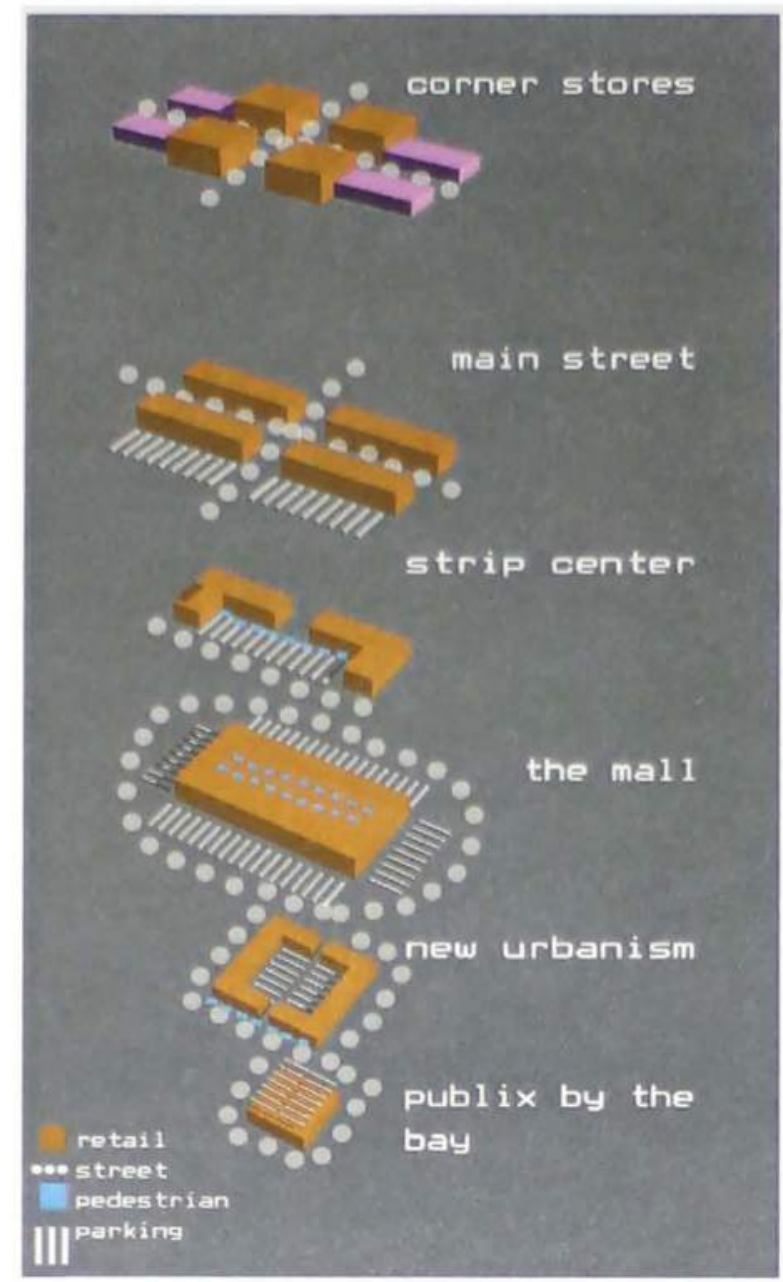

Fig.1. Evolution of Retail Space being ignored. ${ }^{2} \quad$ Likewise design that accommodates cars exclusively eliminates pedestrian activity. "Assuming that car-use

\footnotetext{
${ }^{1}$ Longstreth, Richard. City Center to Regional Mall: Architecture, the Automobile, and Retailing in Los Angles, 1920-1950. 1997.

${ }^{2}$ Bell, Jonathan. Carchitecture: When the Car and the City Collide. 2001: 119.
} 
will increase...we must plan more inclusive cities, urbanism that integrates rather than encourages further separation... architecture and the automobile must learn to co-exist." ${ }^{3}$ The goal should be for all forms of transport to be included in retail design, including buses, automobiles and pedestrians so that one single form does not dominate. This way stronger links can be created to other surrounding land uses.

\footnotetext{
${ }^{3}$ Bell, Jonathan. Carchitecture: When the Car and the City Collide. 2001: 126.
} 
The New Urbanism movement in urban planning and architecture focuses on reviving traditional town planning such as small streets and squares as well as mixed-use neighborhoods to create a sense of community. Supporters of new urbanism believe that instead of accommodating ever-larger suburban sprawl, architects should create denser urban areas by promoting mixed-use and infill projects.

These architectural and land-use techniques are thought to make it easier for people to meet their neighbors and develop the sense of place and community that's often missing in subdivisions where people drive into their garages, close the doors, never see their neighbors and never set foot on the sidewalks because there's nothing to walk to. ${ }^{4}$

New urbanism advocates high density and mixed-use zoning as one of the main tools for promoting change. Supporters believe this approach to planning will result in less automobile traffic and an improved quality of life for urban residents. Peter Calthrope, one of the best known advocates of New Urbanism, states that regional developments should, "Follow town-like principles - housing for a diverse population, a full mix of uses, walkable streets, positive public space, integrated civic and commercial centers, transit orientation and accessible open space."

The belief is that many of the new urbanist techniques are effective and they should be combined with other solutions developed in other successful projects. High density and infill development puts additional strains on urban infrastructure, and are often more expensive development solutions. Many new urbanists tend to promote pedestrian activity and mass transit, and want to eliminate the use of the car, but the car

\footnotetext{
${ }^{4}$ Stark, Judy. "Modern Village Goes Deeper Than Design." St. Petersburg Times February 19, 2000.

${ }^{5}$ Calthorpe, Peter. The New Urbanism: Toward an Architecture of Community. 1994: 15.
} 
has become part of our culture and is not likely to go away. "To deny the car in the city is to deny our lived experience of urbanism. The automobile and architecture have always interacted, playing off one another in complex and inter-related ways." ${ }^{\prime 6}$ This topic is becoming even more important in South Florida as the population is growing rapidly, and traffic is increasing. A recent report ranks Miami-Dade County, as one of the three worst metropolitan areas in the nation with regard to traffic congestion, and adds that, "Transportation is the most serious problem this community faces."

Retail developments can improve the quality of life for the surrounding neighborhood by making shopping accessible and convenient. Architecture can create retail spaces that can build and reinforce community activities and promote social interaction. For example, retail spaces such as local restaurants and coffee shops create centers where neighborhood residents can meet, and public spaces provide people with a place to interact with one another. More interaction improves communication and leads to strong ties and a positive sense of place within a community. Over the past few decades, developers have made retail more economically "efficient," and according to Alex Archimore, this efficiency has lead to the loss of, "Habitat for community function." ${ }^{8}$ He believes communities must find a format for strip centers that combines, "The social benefits of a community center with fundamental retail realities." In Bellevue, Washington, a developer redesigned an older shopping mall with programs to encourage community life. ${ }^{10}$ They included entertainment on weekends and community

\footnotetext{
${ }^{6}$ Bell, Jonathan. Carchitecture: When the Car and the City Collide. 2001: 19.

${ }^{7}$ Westlund, Richard. "Drive Time." Urban Land, April, 2000.

${ }^{8}$ Archimore, Alex. "Putting the Community Back into Community Retail." Urban Land August 1993: 34.

${ }^{9}$ Ibid., p. 34 .

${ }^{10}$ Smiley, David, Ed. Sprawl and Public Space: Redressing the Mall. 2002: 42.
} 
forums so that residents would have other reasons to go there, and it would draw people in who may not have visited the site initially. 


\section{Chapter 4. Retail Environments}

Drive-through stores and big-box retail exemplify how the car has influenced retail design. Drive-through stores include fast food restaurants, drycleaners and even coffee chains such as Starbucks in increasing numbers. Big-box stores are also increasingly popular as they serve a broad geographic area and offer the consumer a wide variety of products. The problem with drive-through stores and big-box retail design is that they limit social interactions, and thus discourage a sense of community within an area. By incorporating smaller retail spaces into a neighborhood, it is easier to develop that sense of community. The smaller scale is also more comfortable for people who are overwhelmed by the size of shopping malls and big-box stores. A retail study from the Harvard Design School explains that, "The very factor that allowed such forms as the shopping mall, big box, and category killer to grow so rapidly and become so successful was also causing their decline." 11

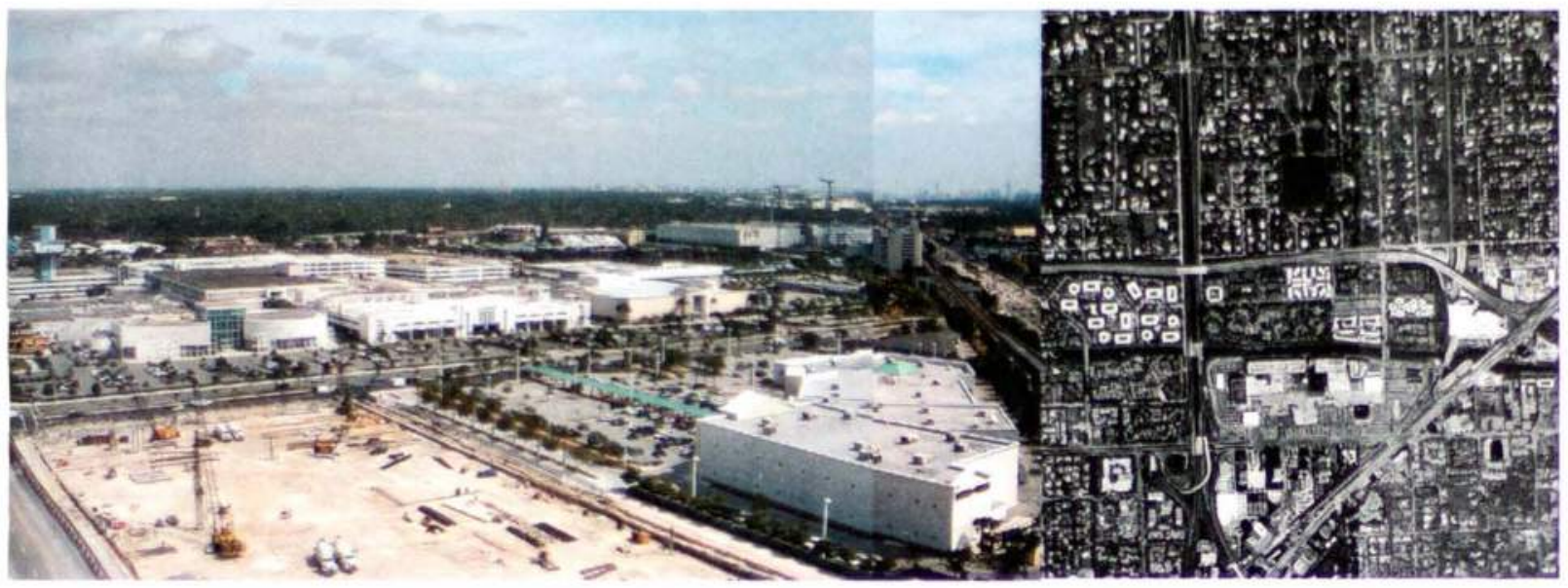

Suburban shopping malls have also become more popular, as

Fig.2. Dadeland Mall

they provide people with a comfortable place to walk without having to worry about problems such as car traffic. It is possible to apply some of the concepts that have made

\footnotetext{
${ }^{11}$ Leong, Sze Tsung. “.... And Then There Was Shopping.” Harvard Design School 2001: 129.
} 
suburban malls successful to central, pedestrian-accessible locations within the city. By creating spaces that are well designed, residents will be more willing to visit the commercial and retail areas around them without having to get in their cars, so they will become more connected to their neighborhood. "The surest way to liven up a downtown is to have people make themselves as home there-literally. Residents, especially if they choose to live at the heart of the city, can make it come alive." ${ }^{12}$ In an effort to create a more sustainable center, this idea was incorporated by designing areas for residential space within the retail center.

\footnotetext{
${ }^{12}$ Lowe, Marica. "Reclaiming Cities for People." World Watch July/August, 1992: 23.
} 


\section{Chapter 5. Pedestrians}

Pedestrian needs can be met in part by creating comfortable and secure walkways so that pedestrian spaces are less dangerous. Editor Judy Stark explains that mixed-use neighborhoods that have retail and commercial uses can be designed to give pedestrians and drivers an equal chance on the street. ${ }^{13}$ Richard Untermann writes that street design is important for creating community interactions and that, "Good streets should serve all uses and users - cars, bicyclists, buses, pedestrians, prams and pushcarts."14 Focusing on street design is important since it creates a better interaction for mixed-use areas, and will address the needs of all the users in the area, attracting more people to visit.

"During the last 40 years, American streets have shifted from attractive, livable spaces shared by cars and pedestrians to their current uses as channels for the high volume of motor vehicles." 15 Richard Untermann provides the following techniques as some of the ways that street traffic can be slowed down, so that pedestrian activity can be promoted: reducing the speed limit; planting more trees/landscaping; creating a bend in the road to slow down speed by cutting off the driver's sight line; swelling the sidewalk out at the corners; creating a median in the middle of the road; surfacing the street with bumpy pavement; reducing the turning radius on street corners to slow drivers down; creating spaces where vehicles can be parked along the street; create shorter blocks so that it is easier for pedestrians to cross the street; establishing mid-block crossing points and longer pedestrian lights, and throttling movement at the entry where cars and people

\footnotetext{
${ }^{13}$ Stark, Judy. "Modern Village Goes Deeper Than Design." St. Petersburg Times February 19, 2000.

${ }^{14}$ Untermann, Richard. "Streets Are for Sharing," Landscape Architecture July 1990: 55.

${ }^{15}$ Ibid., p.54
} 
intersect. ${ }^{16}$ Other techniques that have been successful for promoting pedestrian activity include the widening of sidewalks and the shrinking of streets, and creating lanes for bicyclists. I want to accommodate the car without sacrificing the quality of the street.

\footnotetext{
${ }^{16}$ Untermann, Richard. "Streets Are for Sharing." Landscape Architecture July 1990: 57.
} 


\section{Chapter 6. Case Studies}

I have researched projects being developed that promote a positive interaction between retail and residential spaces. For example, the Publix supermarket on the bay in Miami Beach designed by architect Carlos Zapata, was developed on a relatively small piece of land in a densely populated area.

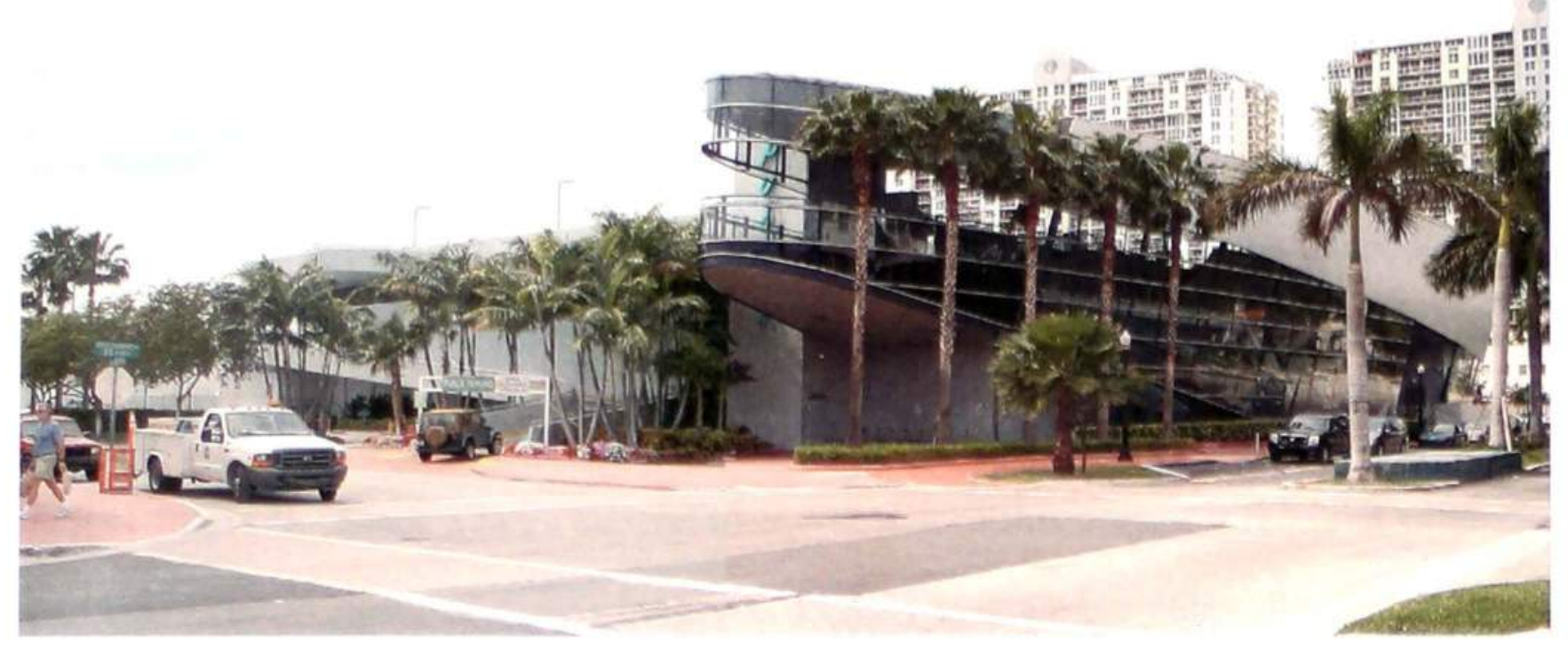

Fig.3. Publix on the Bay

The site is only 1.92 acres, and the store building is approximately 46,000 square feet. ${ }^{17}$ Two levels of parking on top of the supermarket have enabled it to fit into a smaller space and incorporate the automobile in the design as an asset rather than a liability. One façade faces a residential area, and another addresses pedestrians and car traffic on a large street. Miami Beach's Mayor, Neisen Kasdin, explains that this project has been successful because it hasn't altered the character of the immediate neighborhood, but has instead, "Fit within the scale and pattern of the streetscape and coexists with older businesses and residences, enhancing each neighborhood's attraction

\footnotetext{
${ }^{17}$ Kasdin, Neisen. "Preserving a Sense of Place." Urban Land. April, 2000.
} 
and livability."18 This project introduced a creative technique for dealing with parking requirements, and the restricted lot size. Zapata's approach changed the traditional appearance of the structure, allowing it to blend in with the surrounding neighborhood.

Another project that has been very successful is the Uptown District in San Diego, California. This project is a pedestrian-oriented mixed-use retail center and residential development on the 14-acre site of the old Sears store in San Diego's Hillcrest neighborhood. ${ }^{19}$ This project transformed a commercial area into a pedestrian friendly environment and linked the area to the surrounding residential neighborhood. The techniques that were used included: placing retail buildings along the sidewalk on a major street to create active street frontages, slowing down car traffic, and locating parking behind retail street fronts so that parking was still convenient, but not the main focus of the site. Since a large supermarket was part of this project it required extensive parking. The majority of the parking was located in a garage below the supermarket, with additional spaces behind the street-fronting buildings. This way the market was still convenient to pedestrians, but the focus was on the retail storefronts instead of the parking.

The architects, "Tried to provide a sense of streetscapes and a sense that the project is a diverse gathering of architectural images built over a number of years." ${ }^{20}$ This way the project wouldn't look like it was built all at once, but was instead an area with more history. "Courtyard openings allow views into the heart of the shopping district,

\footnotetext{
${ }^{18}$ Kasdin, Neisen. "Preserving a Sense of Place." Urban Land. April, 2000.

19 "Uptown District: San Diego, California" 8 Oct. $2003<$ http://www.gast-hillmer.com/uptown.html>

20 "Unsprawl Case Study: San Diego's Uptown District." 17 Sept. 2003

$<$ http://www.terrain.org/unsprawl/1/>
} 
visually linking it to the activity of the thoroughfare." ${ }^{21}$ The residential portion of the project was a combination of townhouses and apartments, some of which were located on second stories, above retail spaces on the first floor. The parking for these spaces were also mainly located underneath the building, and since the residences were orientated towards the street, it encouraged the residents to interact with the street activities, and focus less on their cars.

21 "Unsprawl Case Study: San Diego's Uptown District." 17 Sept. 2003

$<$ http://www.terrain.org/unsprawl/1/> 


\section{Chapter 7. Project Site}

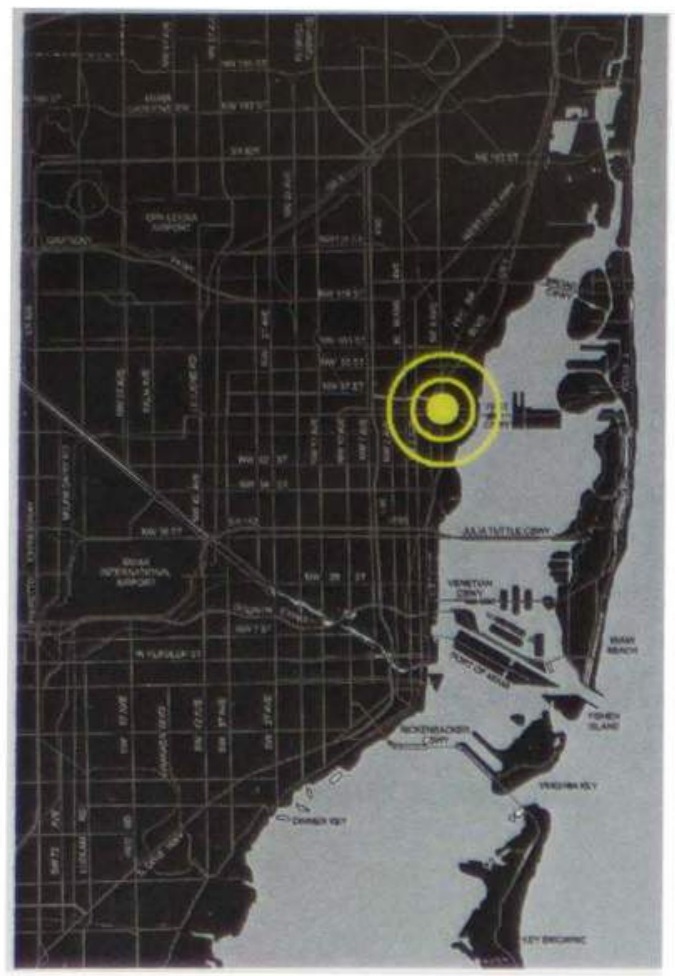

The project site is approximately 550,000 square feet, and is on Northeast $79^{\text {th }}$ Street and Biscayne Boulevard in Miami, Florida. The current shopping plaza at this intersection, Biscayne Plaza, was built in 1954, and has almost reached its build out capacity. The site limits expansion so it will not accommodate a major regional shopping center of the character that developers currently consider profitable, but instead presents an opportunity for a

Fig. 4. Regional Map

local shopping area that can encourage redevelopment in its immediate surroundings. This center is located at the intersection of two important roads of local historic significance: Biscayne Boulevard (US 1), a major north-south commercial corridor and locus of some of the earliest development in this region at the beginning of the twentieth century; and Northeast $79^{\text {th }}$ Street, a prominent east-west corridor that is a causeway connecting the

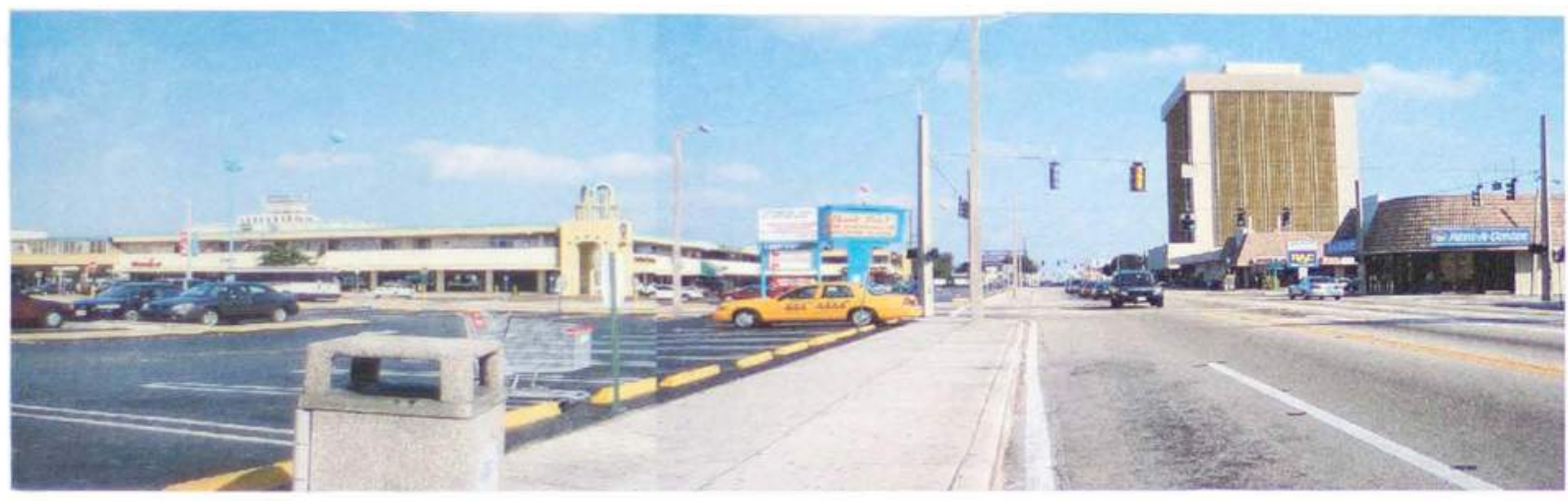

Fig. 5. View from Biscayne Plaza 
city with Miami Beach. The west side of the property borders the Little River canal, and beyond it, the tracks of Henry Flagler's original Florida East Coast Railway. The surrounding residential area, largely composed of small, late nineteenth century bungalows interspersed among post war starter homes for returning veterans, lies primarily to the north and west of the site. This center serves the neighborhoods now known as Little Haiti, El Portal and Miami Shores neighborhoods, largely a low-income, and diverse population. As was the case with most such mid-century shopping centers, Biscayne Plaza has a large amount of surface parking. This separates the pedestrian on the principal streets from the retail activity, and at night, when the parking is empty, the area becomes a dangerous place. 

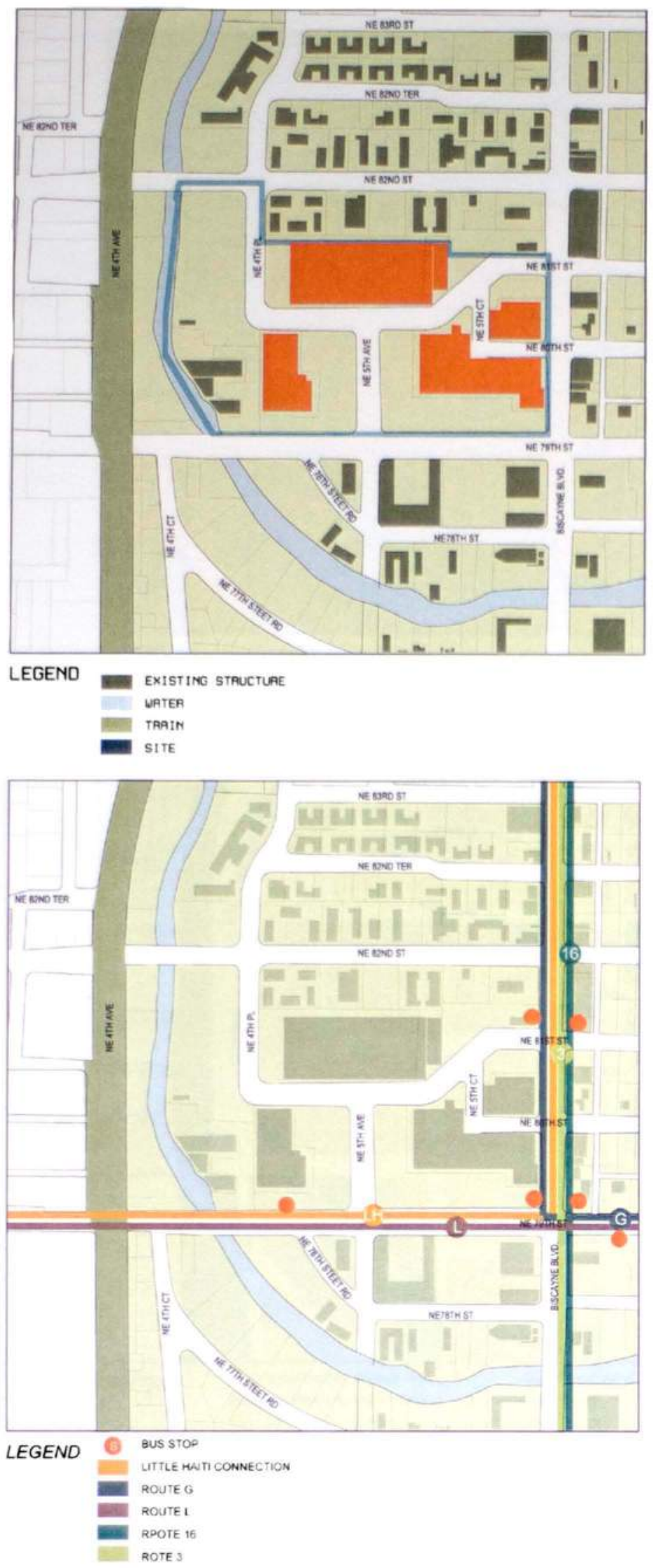

Fig. 6. Site Map and Bus Routes 

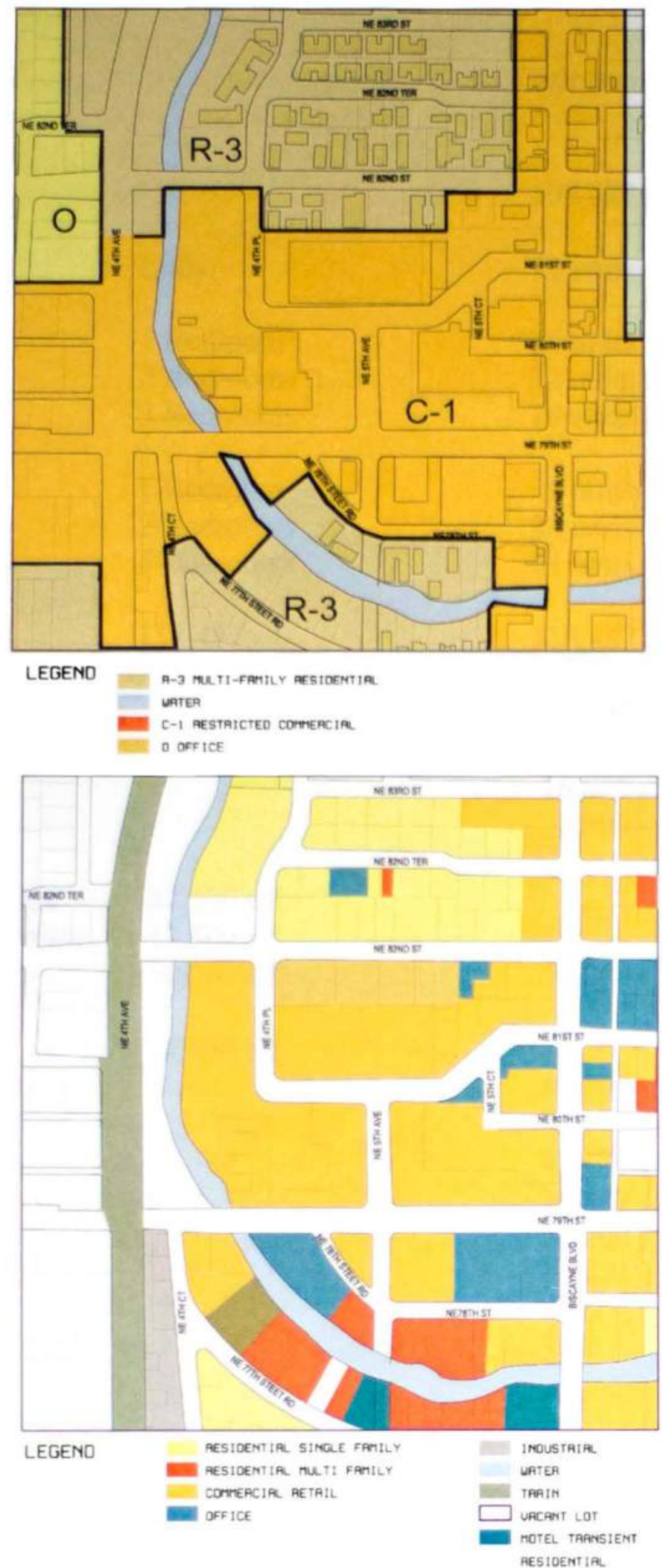

7. Zoning and Land Use 
Chapter 8. Program

Gross Site Area

Residential Space

Block 1

Block 3

Block 4

Office Space

Retail Space

Daycare

Gym

Supermarket

Total area sales Total area service Total area

Restaurant

Vocational facility

Park

Plaza

Library

Post office
767,000 s.f.

299,027 s.f.

Lofts

52 units

26 units

22 units

10 units

9 units

36 units

24 units

118,487 s.f

118,487 s.f

175,462 s.f.

175,462 s.f.

16,000 s.f. 7,300 s.f.

50,000 s.f.

4,830 s.f.

16,000 s.f.

82,334 s.f.

16,807 s.f

25,000 s.f.

14,472 s.f. 


\section{Master Plan Parking Breakdown}

This breakdown is based on the City of Miami, Florida zoning code for C-1, restricted commercial off-street parking requirements. For non-residential use, the requirement is: one (1) space per three hundred (300) square feet of gross floor area for other nonresidential uses. For multi-family residential spaces, the requirement is: one (1) space for each efficiency or one-bedroom unit, two (2) spaces for each two-bedroom or threebedroom unit, and three (3) spaces for each unit with four (4) or more bedrooms. ${ }^{22}$

Use

Residential

Lofts

1 Bedroom

2 Bedrooms

3 Bedrooms

4 Bedrooms

Visitors

Retail

Office

Civic

Total

Site Parking Spaces

Residential

26 One person unit

22 Two person unit

10 Three person unit

Visitors

Retail Space

Office Space

Total Spaces in Site

Total Spaces Required
Total Units

52

55

76

10

24
Spaces

52

55

152

20

72

34

584

395

131

1,495

\section{2} . 2 4

26 cars

44 cars

25 cars

9 cars

60,432 s.f.

6,224 s.f.

201 cars

20 cars

342 cars

325 cars

\footnotetext{
${ }^{22}$ City of Miami, Florida, Municipal Zoning Code, 2004.
} 


\section{Chapter 9. Design Solution}

My design focuses on linking the retail activity with the residential space around it by addressing the relationship between pedestrian and vehicle traffic. In redesigning the existing retail space, I use strategies developed by the New Urbanism movement as well as other projects that have created a sense of place for the community. I consider this to be a good site to apply new design strategies, as this area, especially along Biscayne Boulevard is becoming a focus for redevelopment in Miami. Currently the shopping area is on a very large site, so I will extend streets into the lot to make it connect to the city grid. This will help bring the street into the mall and the mall out into the city.

The project was developed in two stages, the first stage was to create a master plan for the site, and the second stage focused on a more detailed development of one of the blocks in the master plan. In this block, the parking for the retail space is located under a pedestrian plaza. This provides an immediate connection to the car and easy access between the two programs. The levels in the plaza have been manipulated in order to create openings that bring light and air to the parking area below, and allow people to sit on the upper level. Most of the plaza is surrounded by retail space, creating pedestrian traffic, which promotes activities within the plaza area.

My project breaks the mass of the buildings, and blurs the boundaries between the retail space and the street, and between the shopping center and the surrounding neighborhood. The space accommodates different types of programs for various uses, so that the spaces can be used to incorporate community and social functions as well as shopping. This idea goes against the original concept of the retail mall, but by including multiple uses, the area can become a more active and lively space. 
My design strategies include: breaking the mass of the site, and re-connecting the site which had been consolidated to build the original shopping center, to the current city grid and street pattern. My project establishes a boundary/buffer zone between the cars and pedestrians by placing them at different levels, and increases the density of the area by integrating office and residential apartments above the commercial space. To accommodate the car and avoid using a great amount of surface parking, a network of parking spaces has been created that links parking on the basement level to the plazas and to the parking spaces on top of the buildings in the center. With this project I apply the strategies learnt from research projects to design a place interesting enough so that people from surrounding neighborhoods will be motivated to walk there. My project balances pedestrian and car traffic so a positive connection is made between the retail and

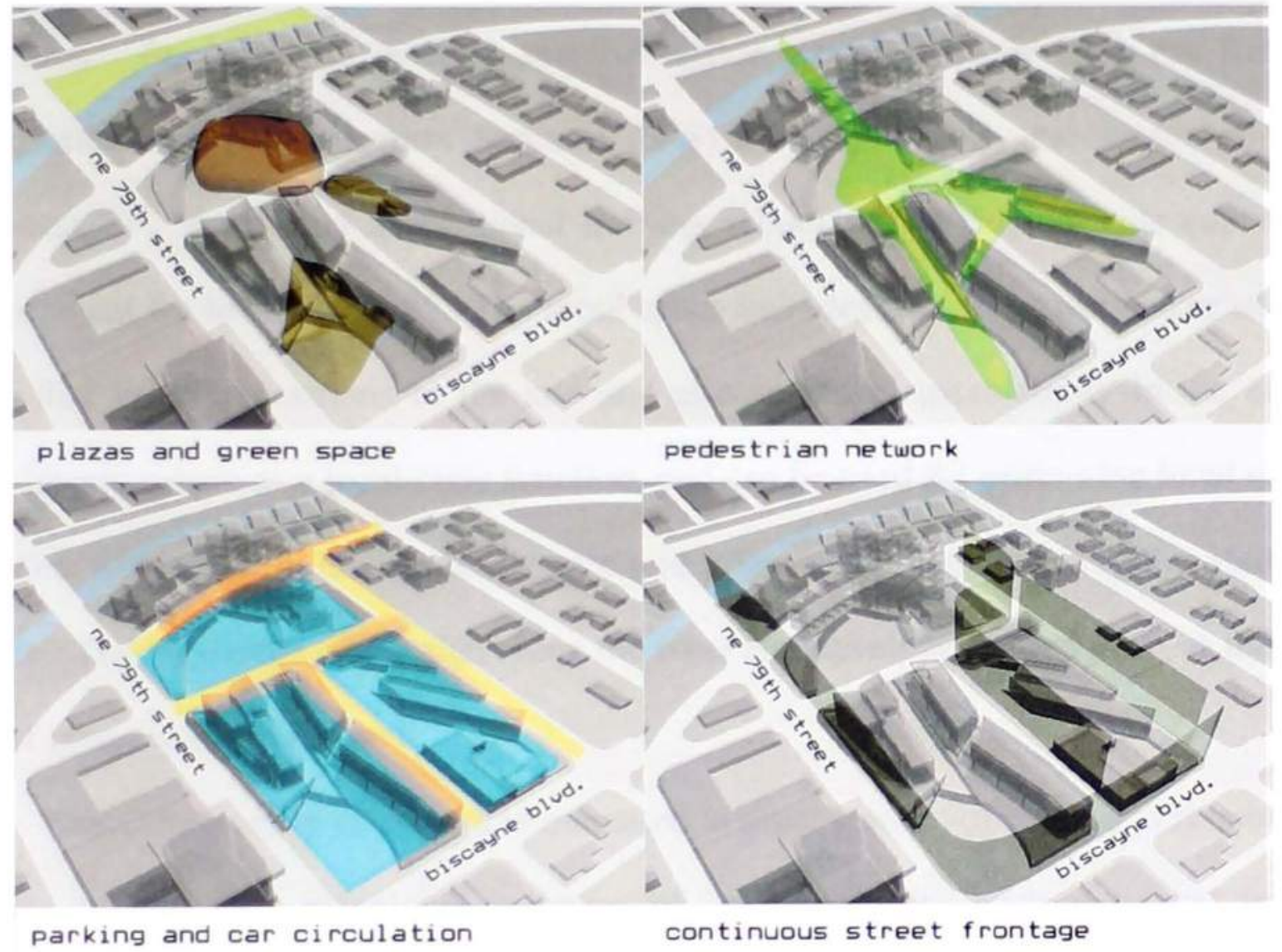

Fig. 8. Strategy Diagrams 
residential areas. To make the presence of the car more evident the car is lifted (terraced) from the pedestrian zone and a car wash and drop off for the residential buildings on the second level have been proposed. This new proposal for Biscayne Plaza has the potential to become a center for the community, and provide surrounding residents with a civic and cultural focus, something that the area is currently missing.

The master plan for Biscayne Plaza includes a mix of residential, retail, commercial and parking space. The residential area provides housing for a mix of low and middle-income residents by providing lofts in the area close to the immigration building, as well as townhouses along the river shore, that tie in with the current area demographics and housing market. The office space relates to the surrounding neighborhood by including spaces targeted to tenants who can provide services for the local area. For example, a legal services office would generate business from the Immigration and Naturalization Services (INS) building directly across the street on Northeast $79^{\text {th }}$ Street, and a vocational training school would help provide educational advancement for local residents. The retail space includes a small grocery store and post office that bring pedestrians to the site and also increase sustainability in the area. A small library serves as a local civic function, and can be used for promoting local cultural activities. Other spaces include a day care and gym, which will bring regular visitors to the site. The west edge of the site, along the river is redeveloped into a park, as there is a lack of green space in the area.

Since the density of the site is increased, a great amount of parking is required. In contrast to the more traditional isolation of uses and infrastructure typical to most contemporary zoning and construction, the parking spaces in this project are mixed into 
the different layers of the program. Across from the INS building, an open plaza can be used for civic activities, including the protests and local rallies that have long characterized the communities of immigrants from different parts of the world who make their homes in Miami. In the evenings - or under a different social/political climatethis same space might possibly serve as an open amphitheatre for showing movies or holding cultural activities. It is designed as neutral/flexible space that can accommodate a number of different functions.

This project identifies and documents an existing deficiency in the urban fabric of Miami, and suggests an approach to ameliorating that deficiency, and, in the body of this thesis project, proposes a design solution that demonstrates the viability of that approach. By suggesting a combination of programmatic uses for its spaces, increasing density, and incorporating techniques that support urban continuity and pedestrian and vehicular traffic, Biscayne Plaza can be developed into a sustainable center that is an asset to the surrounding community.

The following pages show the designs for the project: 


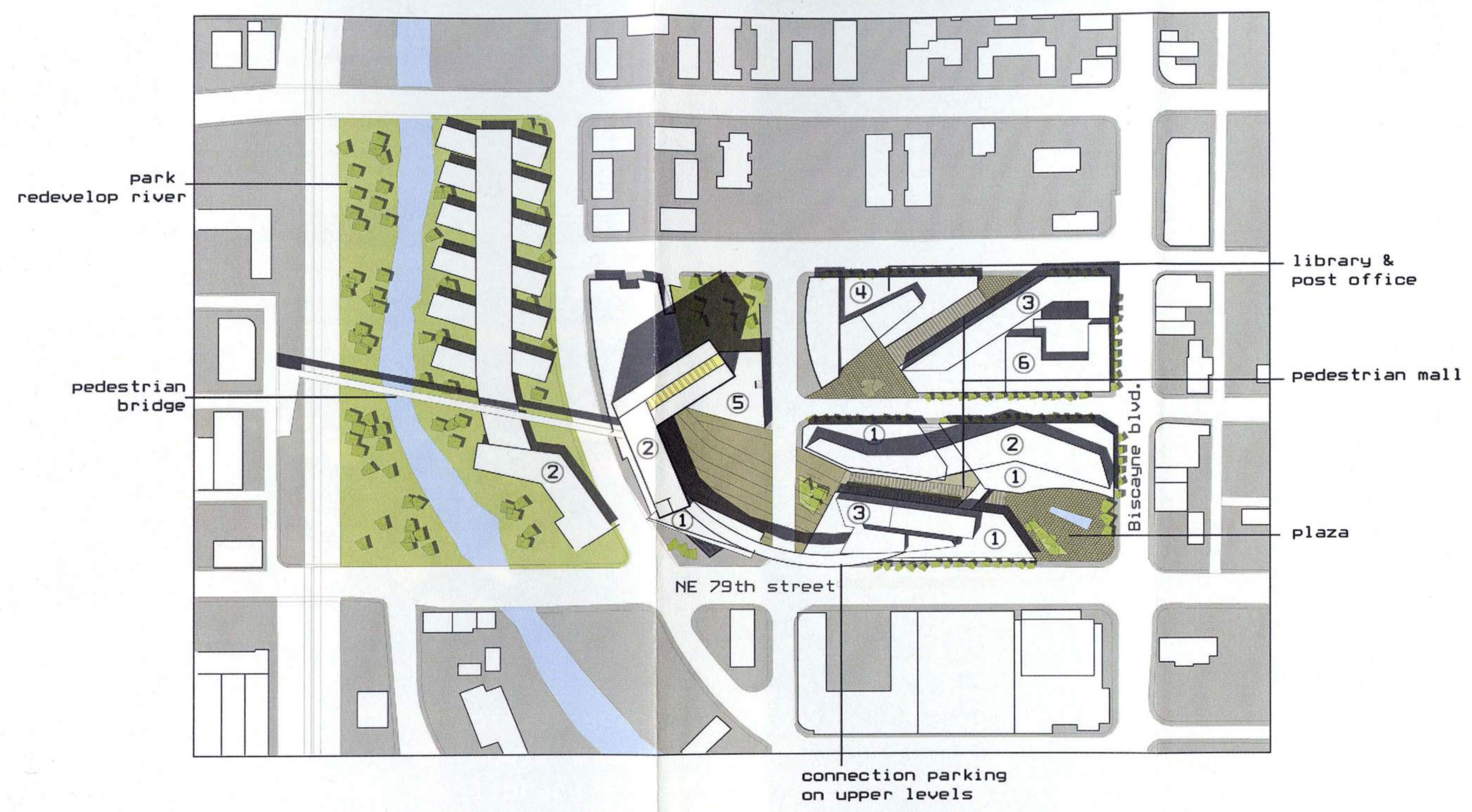

master plan

(1) retail space

(2) residential space

(3) office space

(4) library + post office

(5) movie theater

(6) existing building to remain 


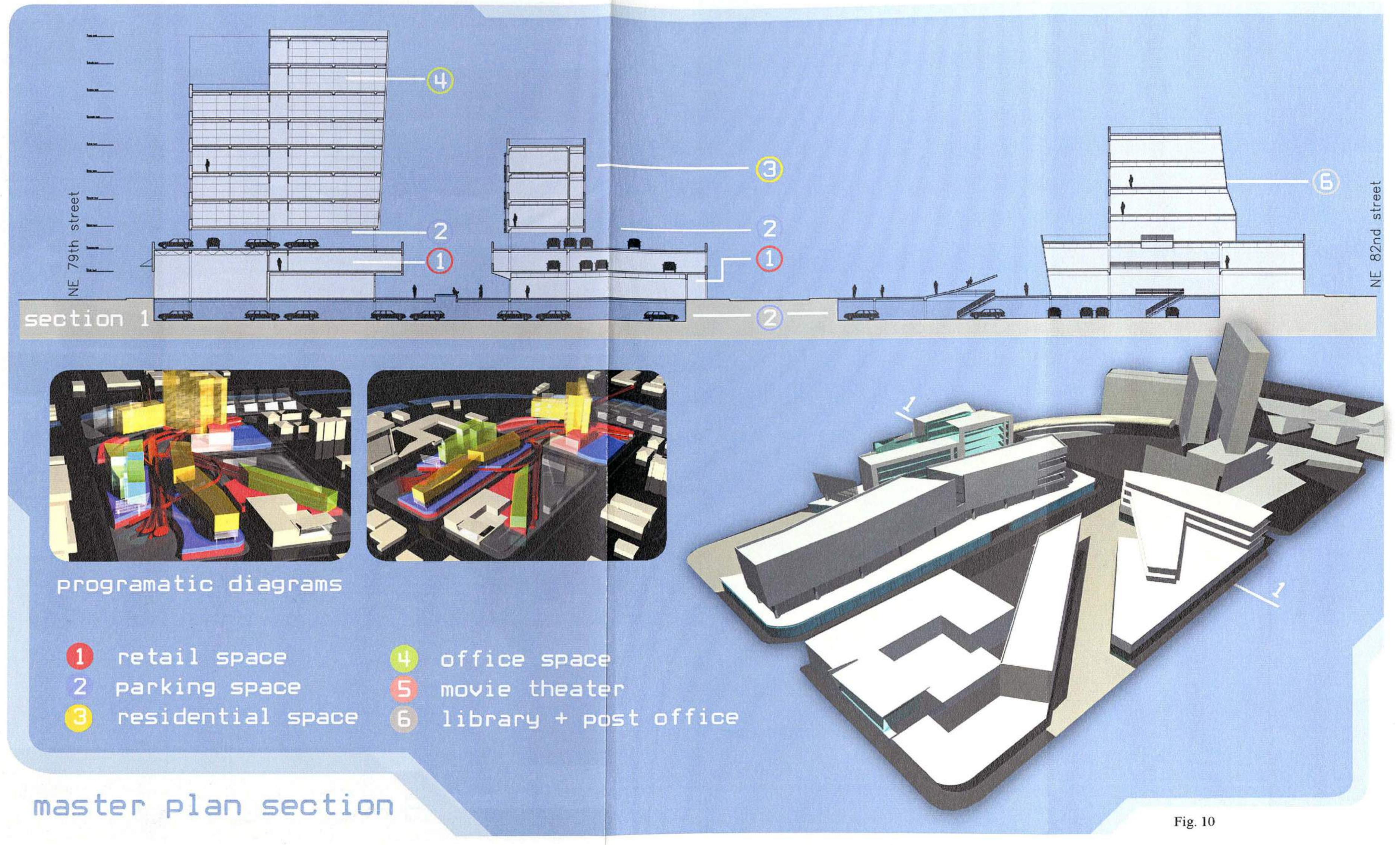




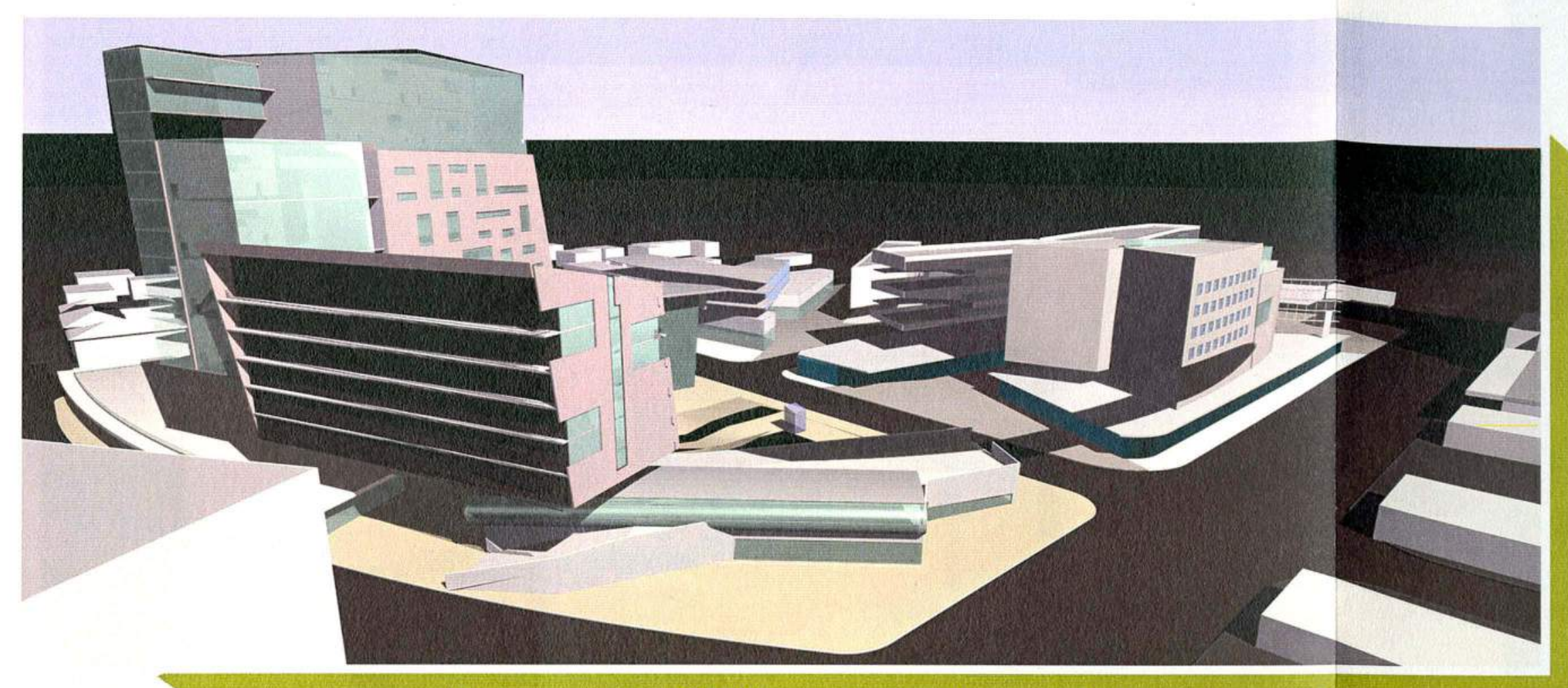

north east 79 th street looking east

view of plaza and car wash

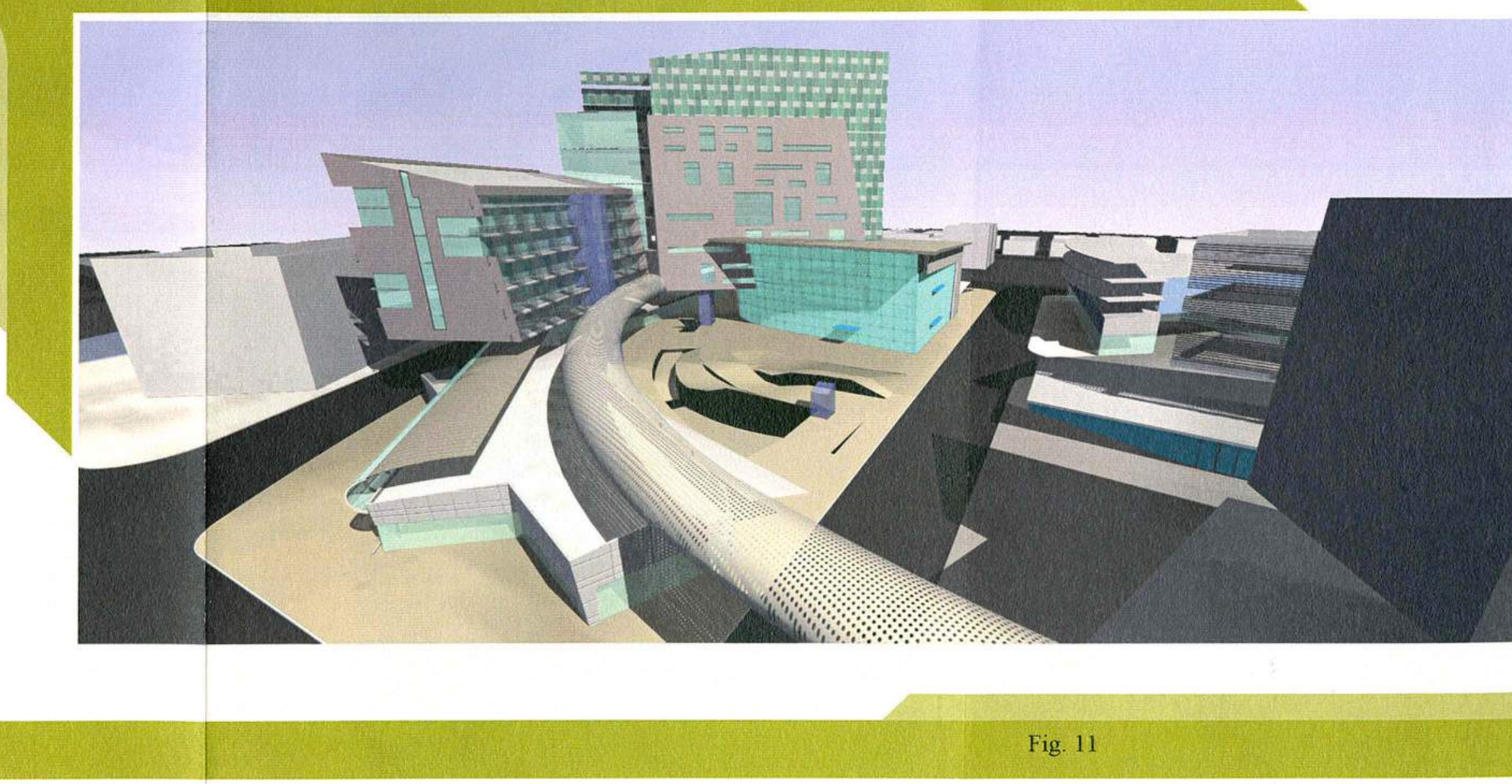




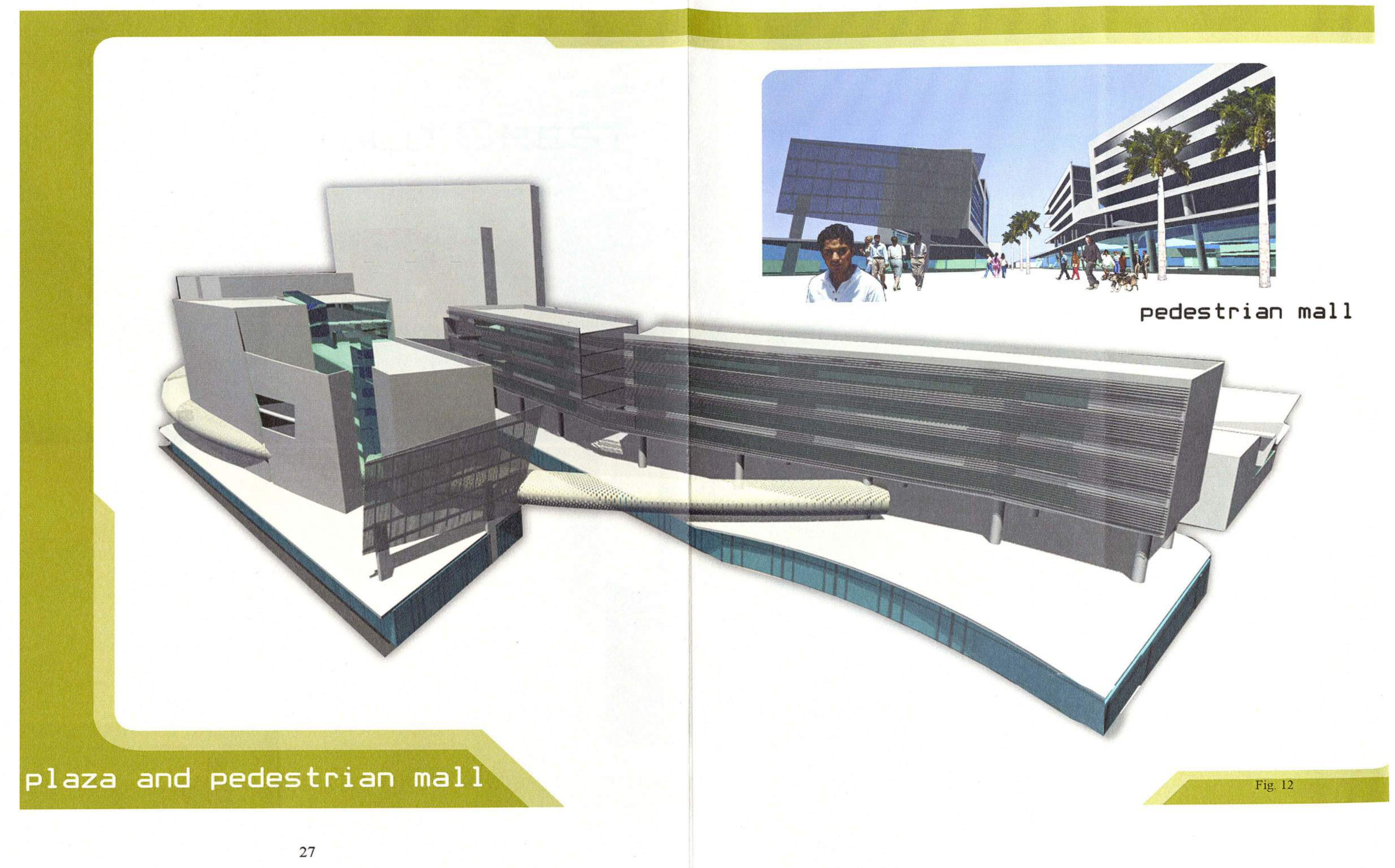




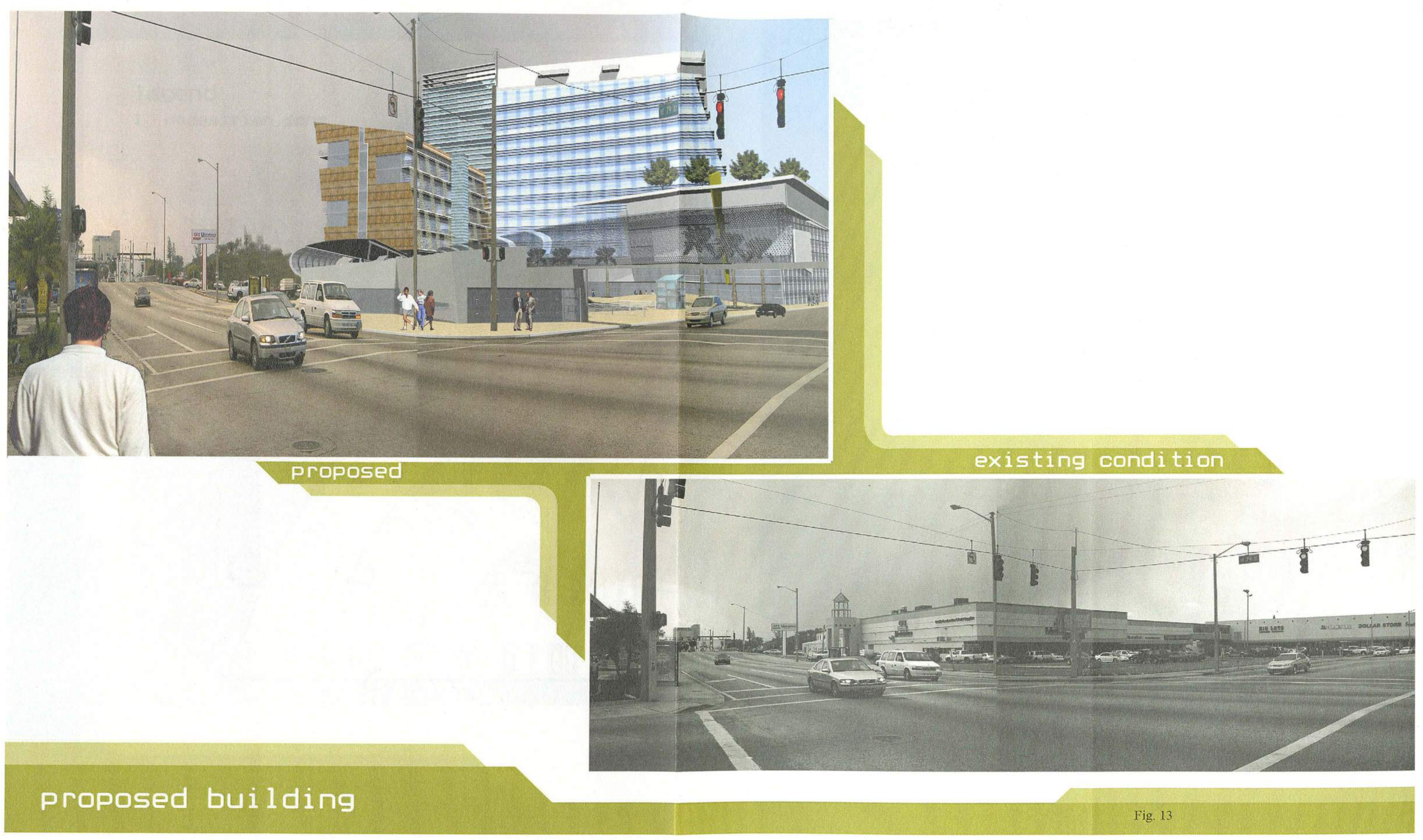




\section{legend}

1 pedestrian zone
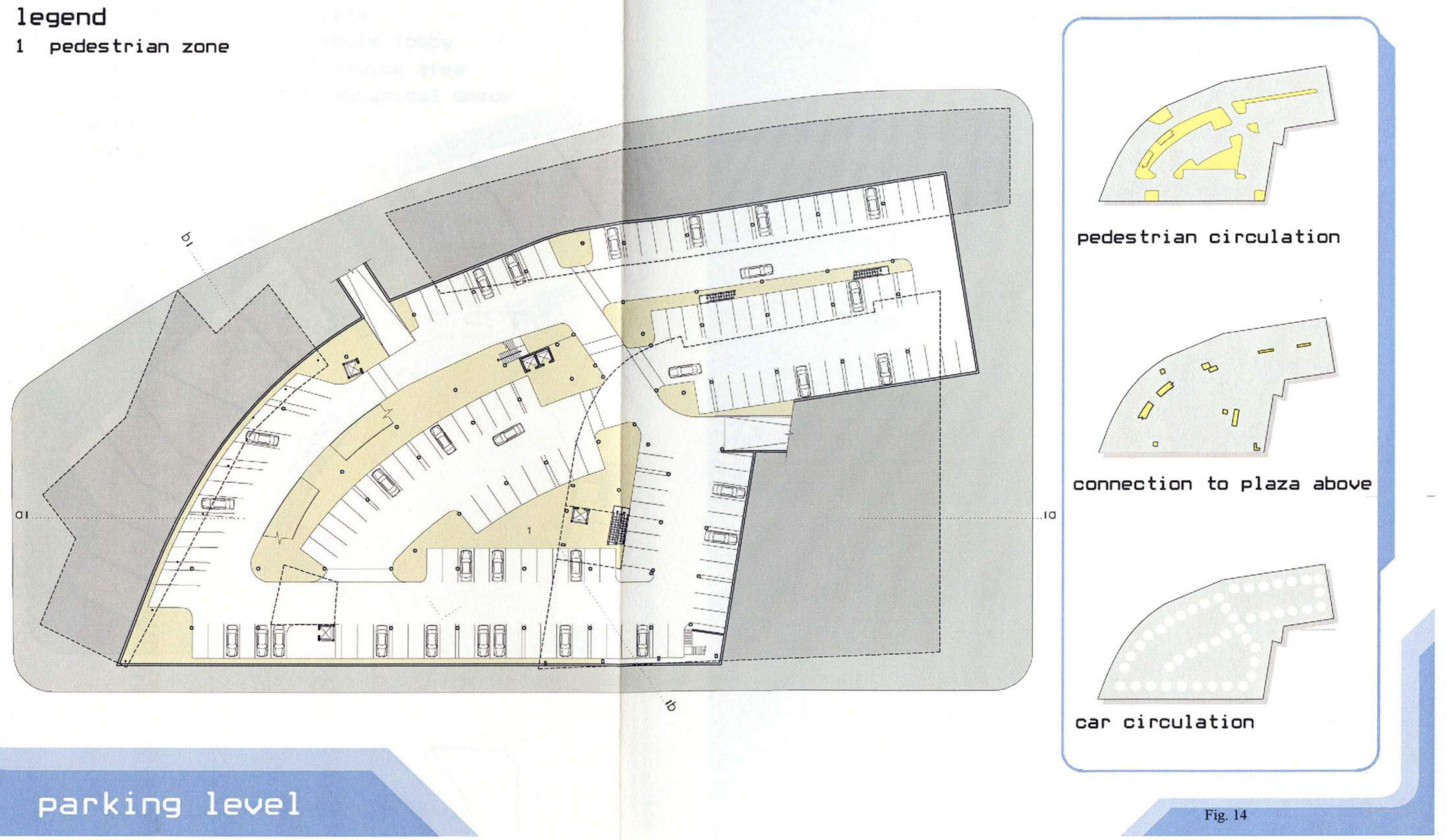


\section{legend}

1 restaurant

2 bookstore

3 retail

4 gymnasium

5 beauty salon

6 grocery store

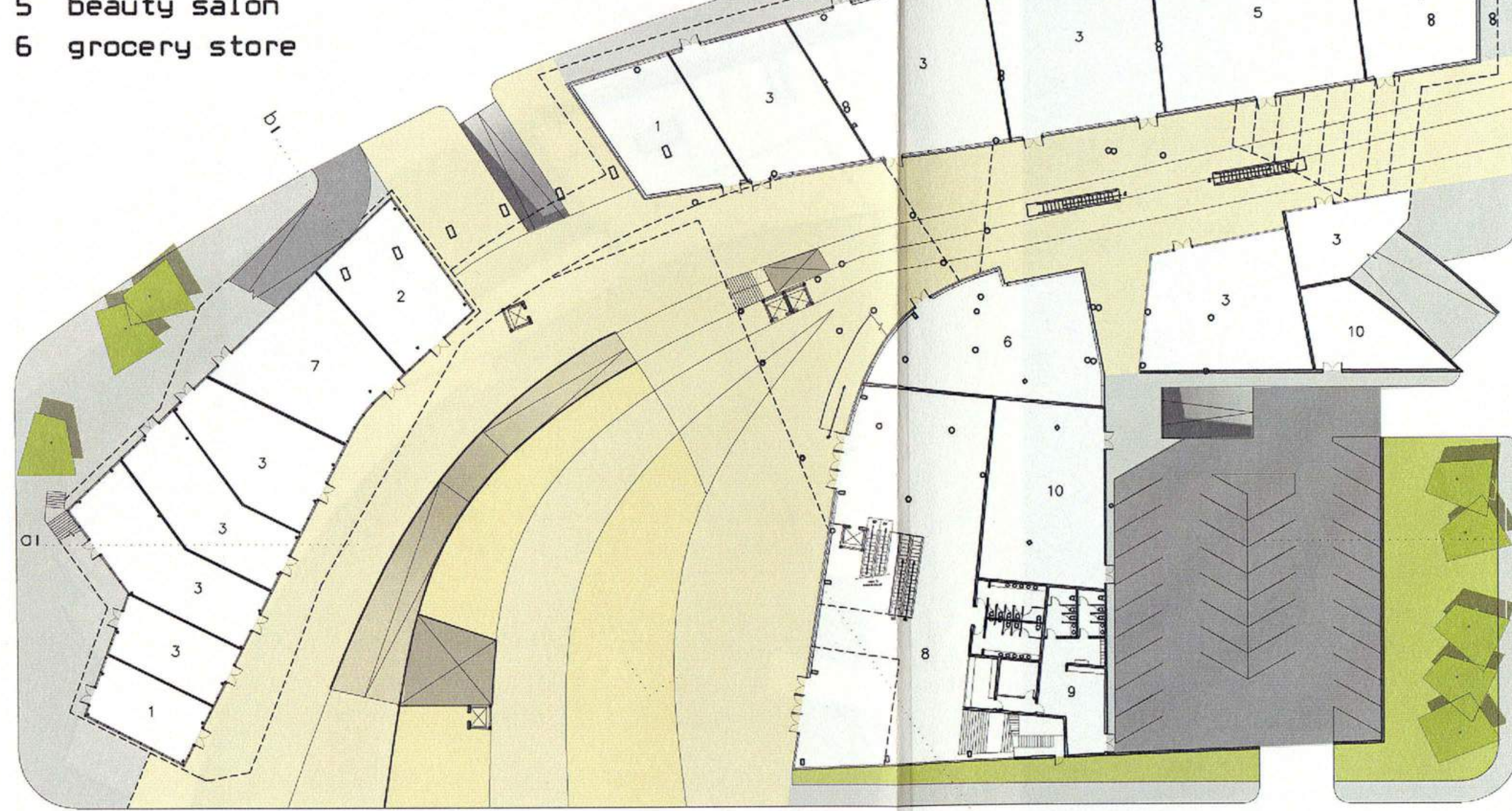

7 cafe

8 movie lobby

9 service area

10 mechanical space

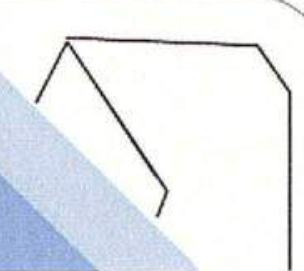

ground level

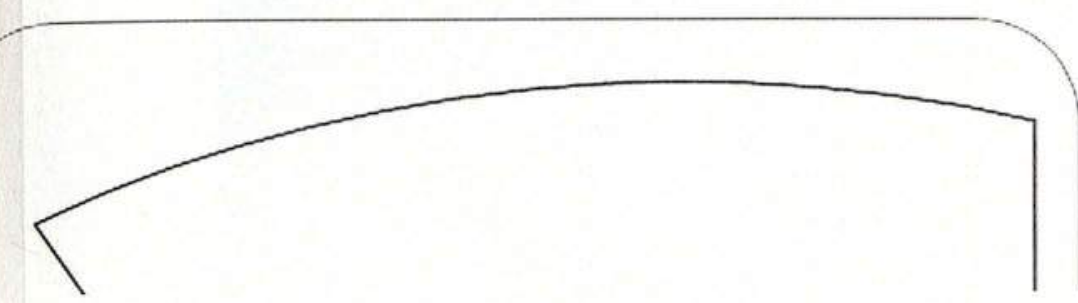

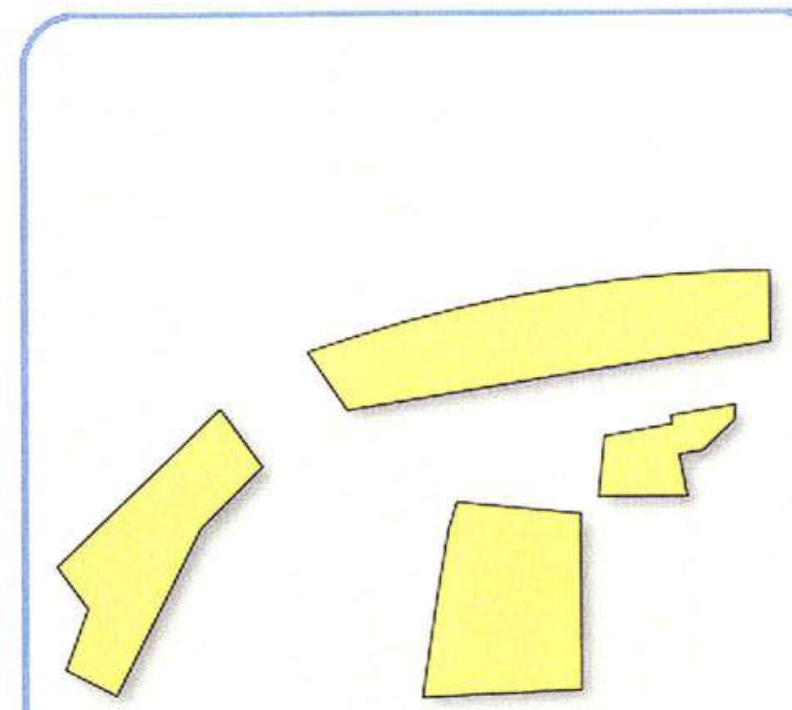

structures

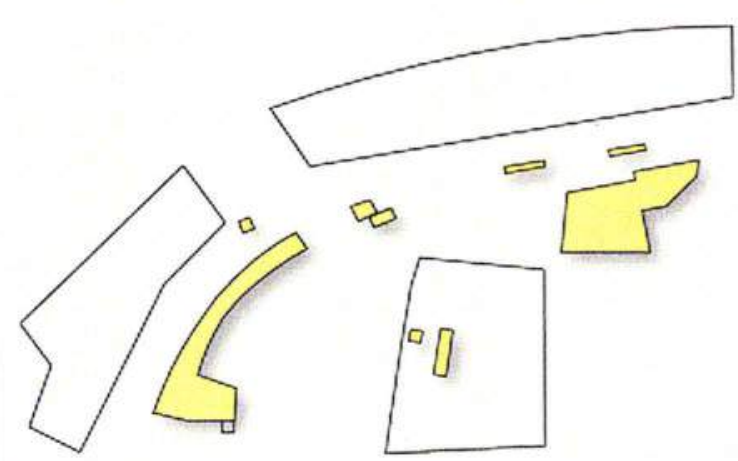

connections to parking below

Fig 15 


\section{legend}

1 car wash

2 movie lobby

3 movie theater

4 playground

5 park

6 residential parking
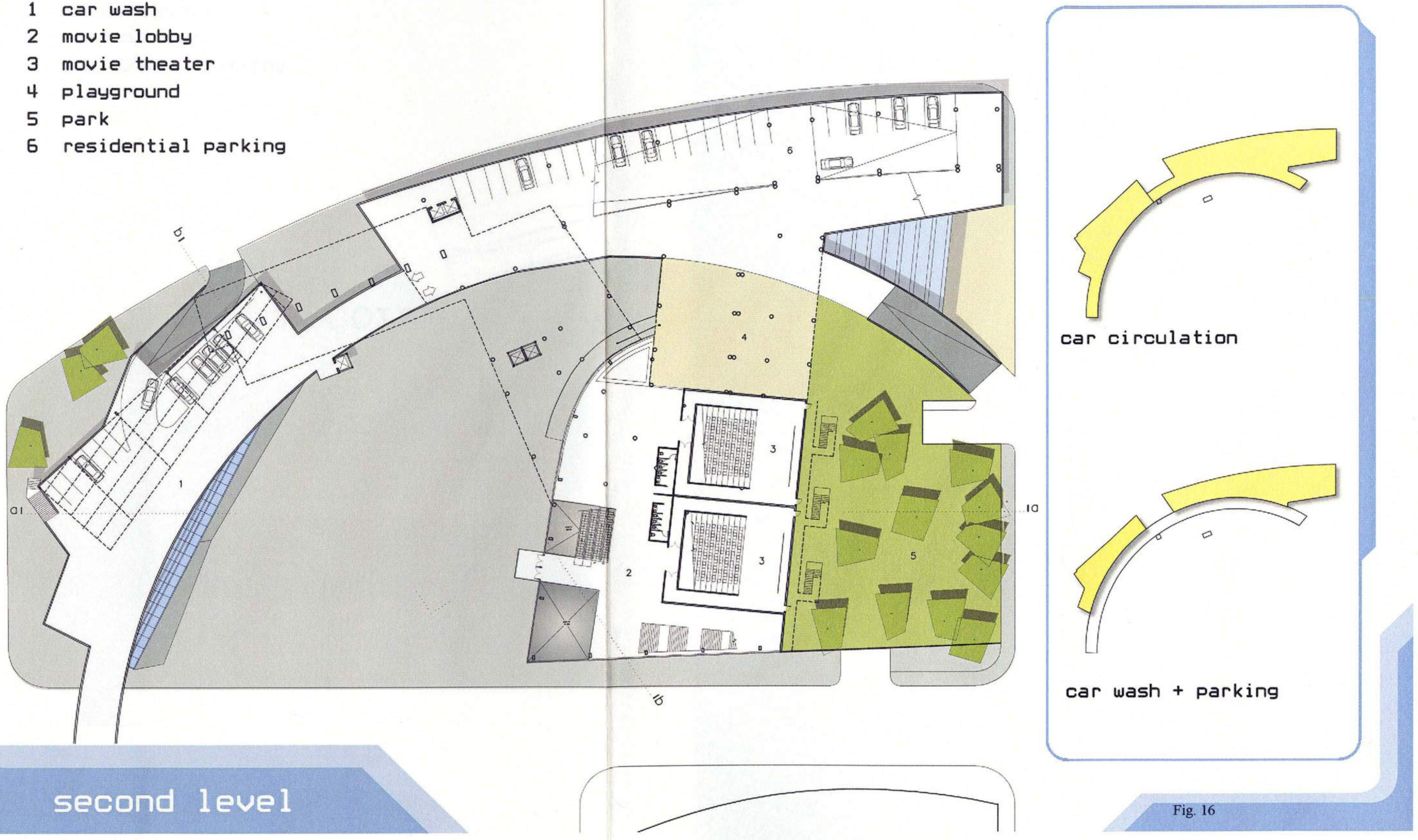


\section{legend}

1 movie theater

2 control room

3 residential parking

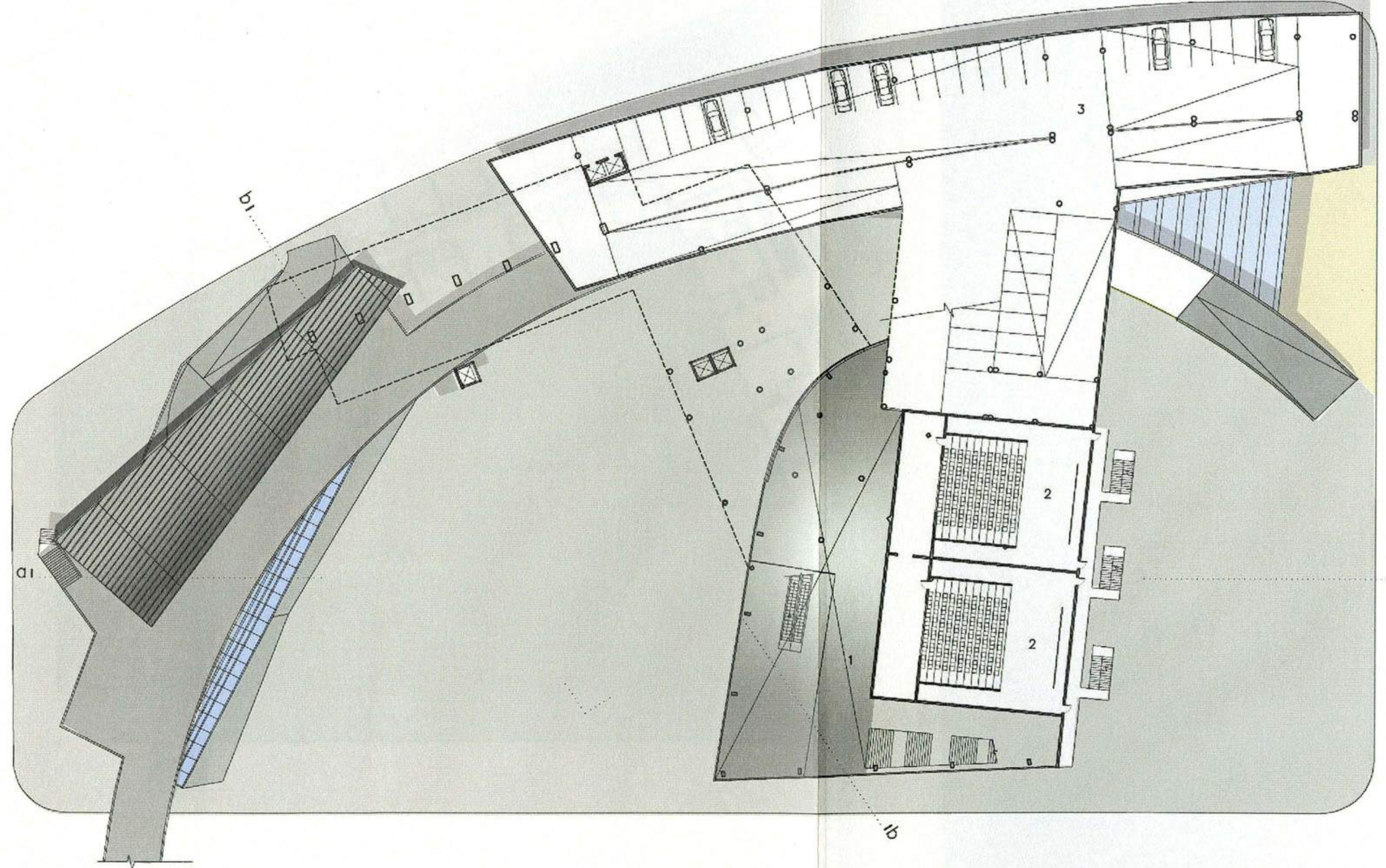

third level
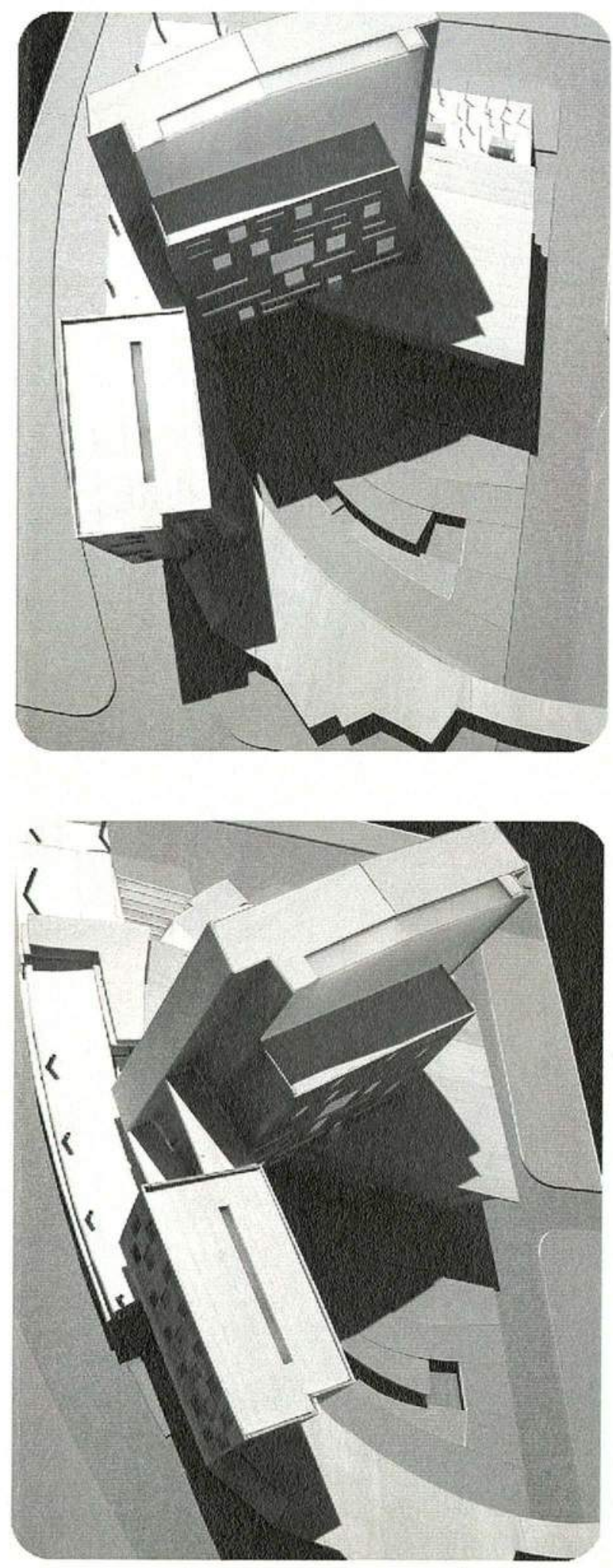

Fig. 17 


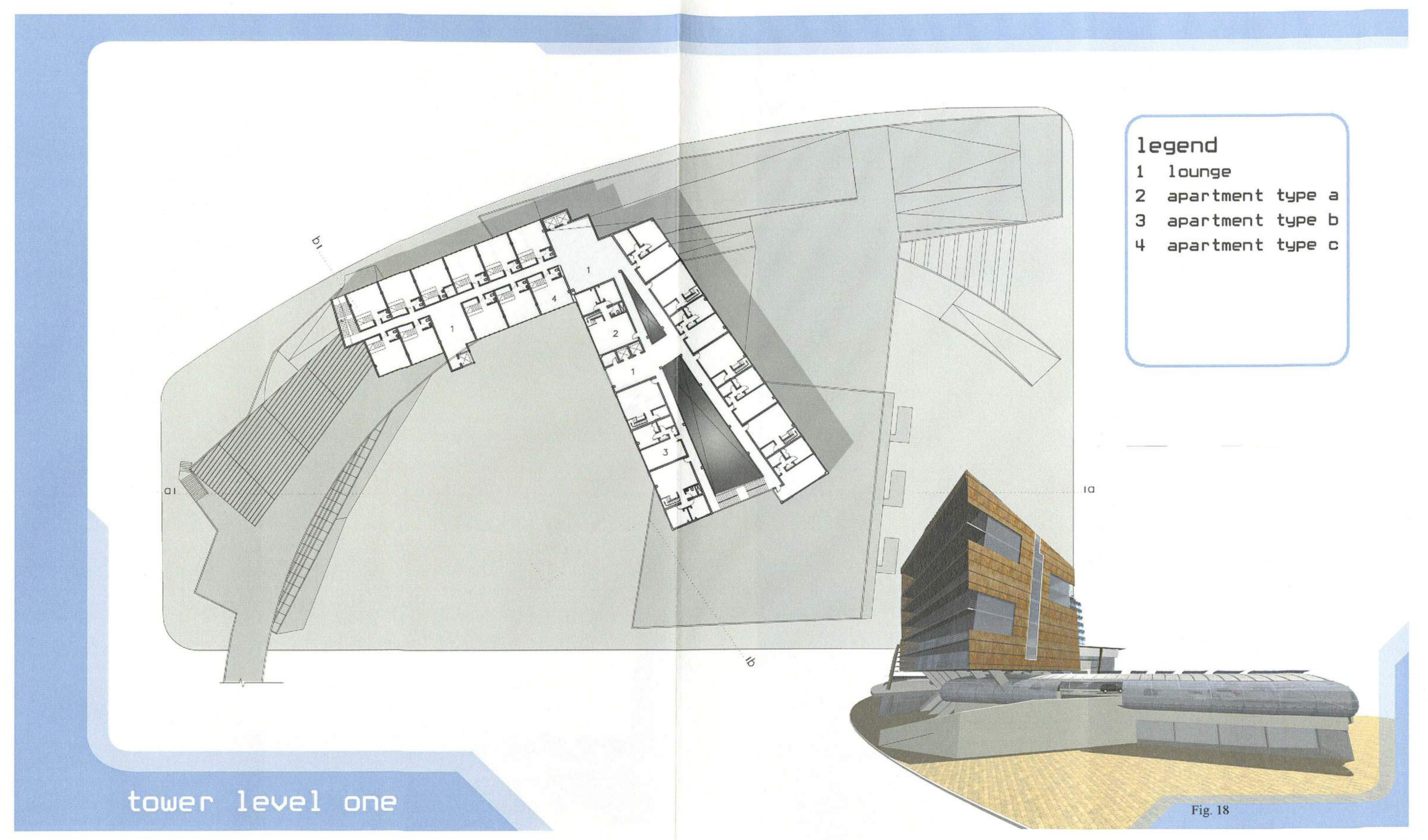




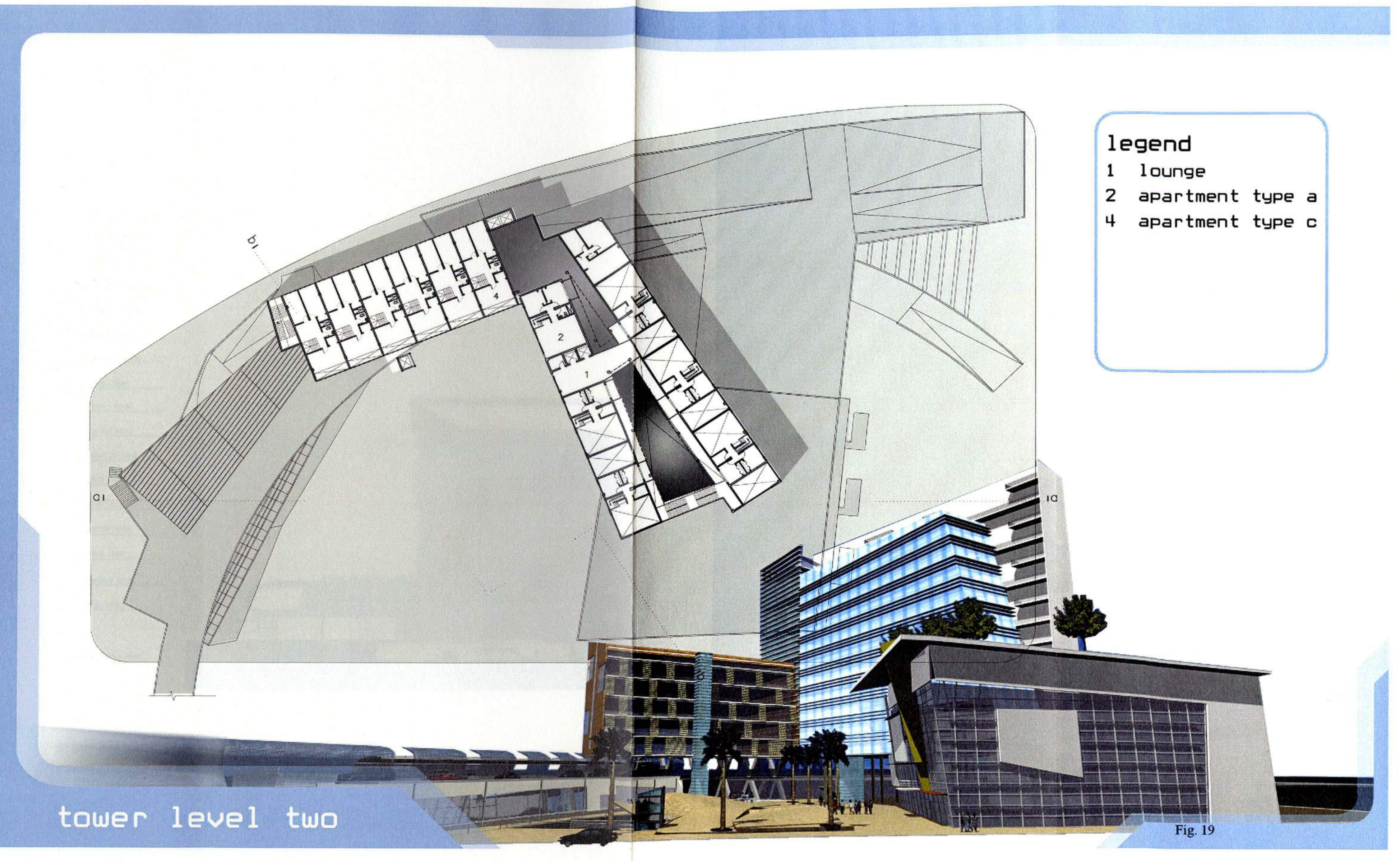




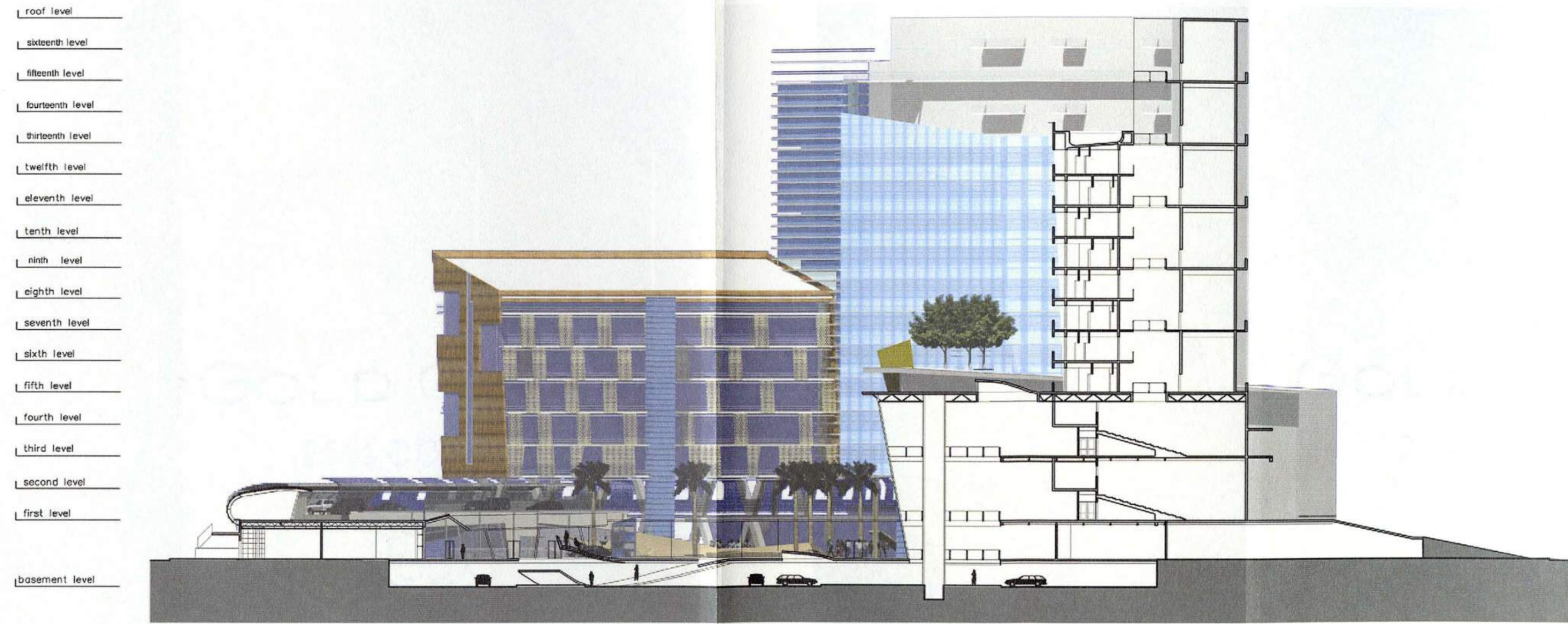

section a-a 


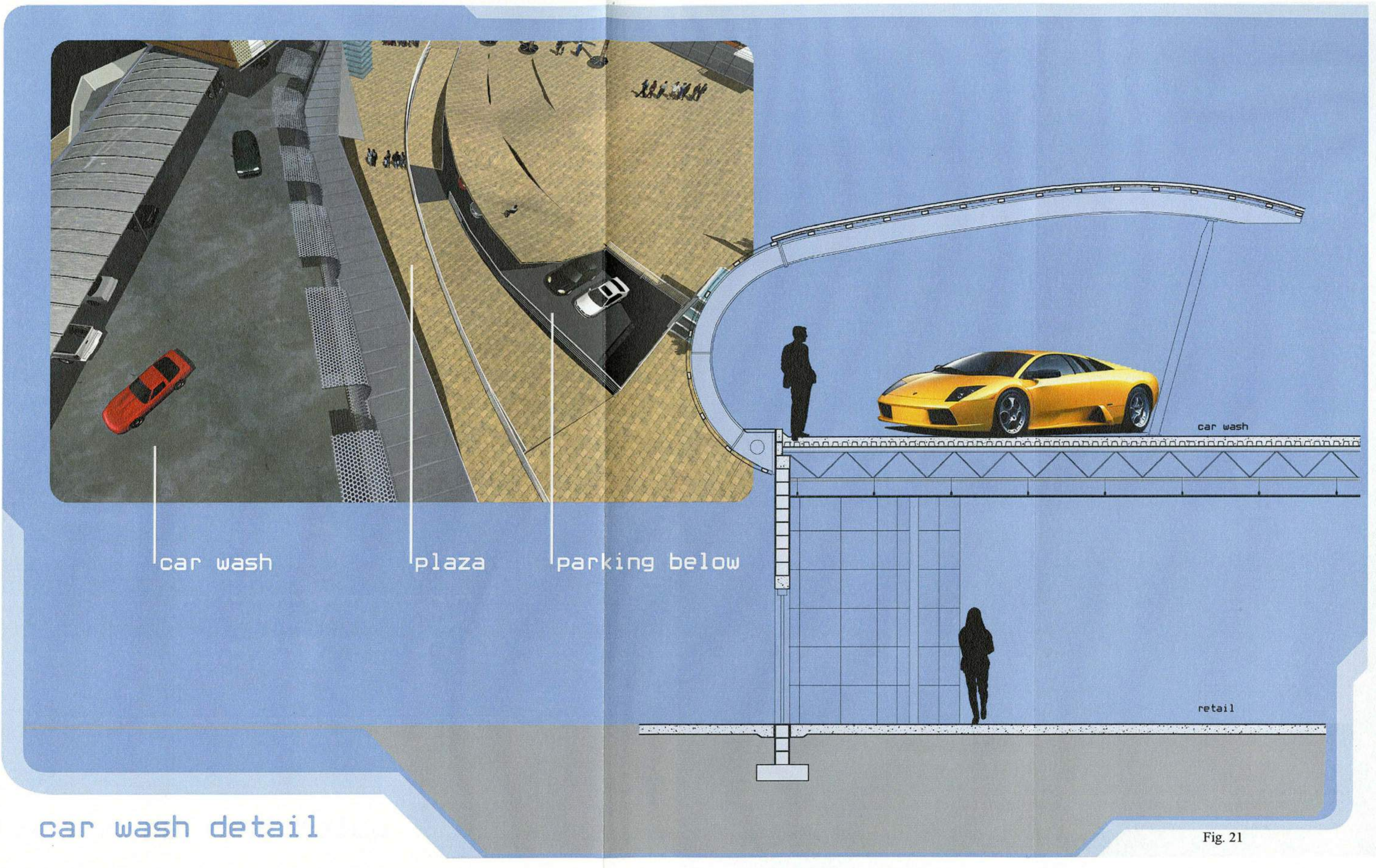




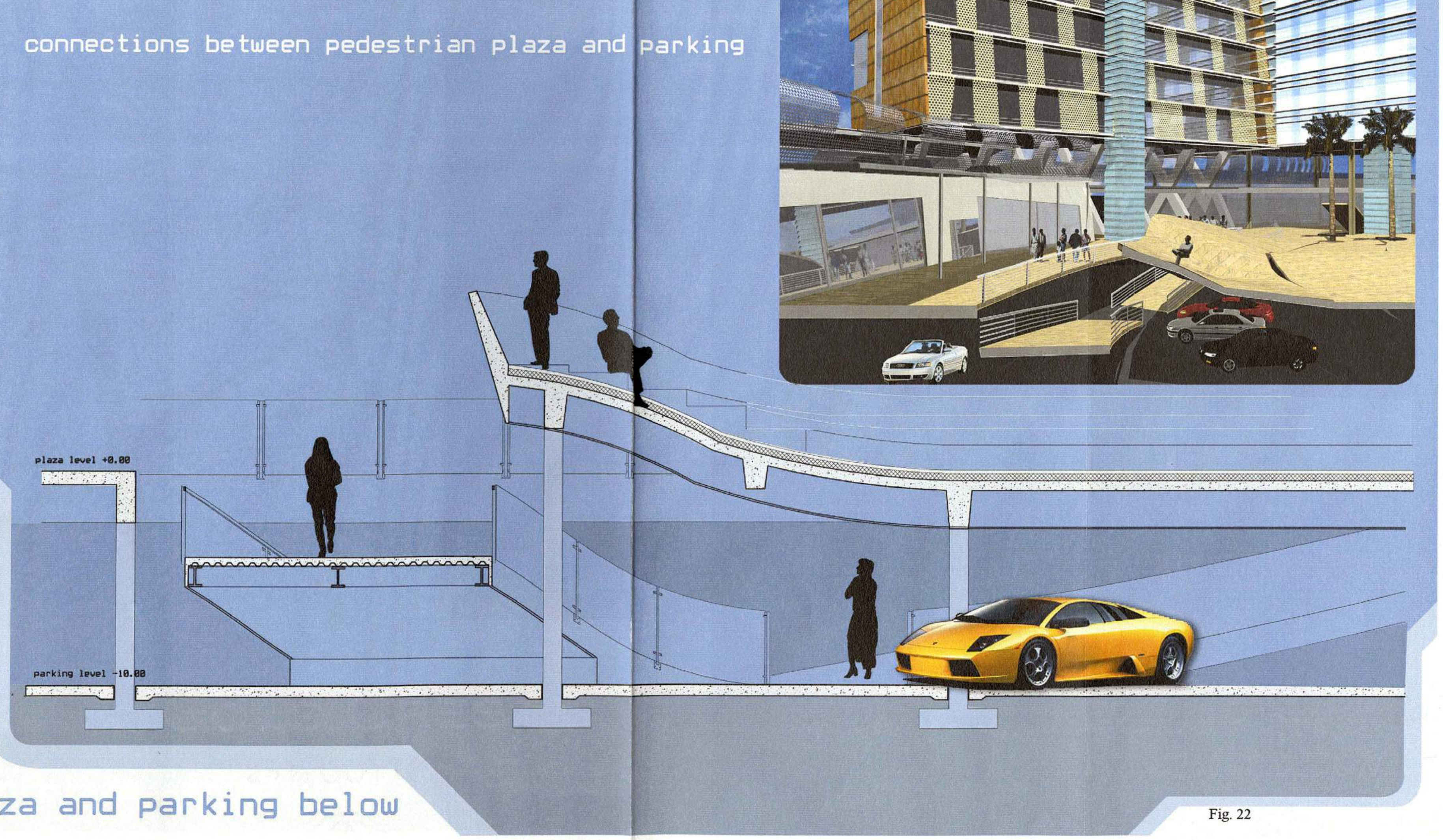




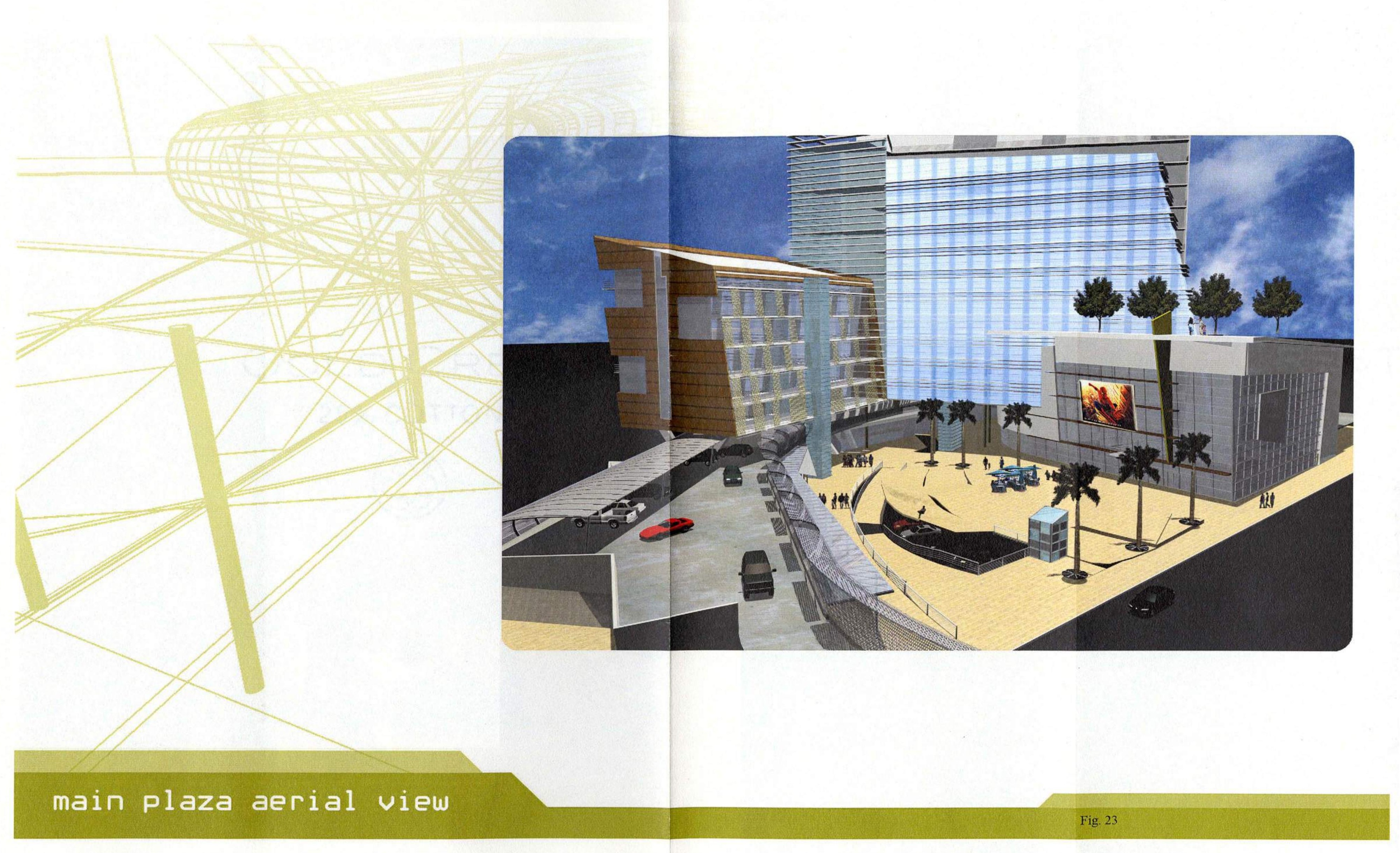




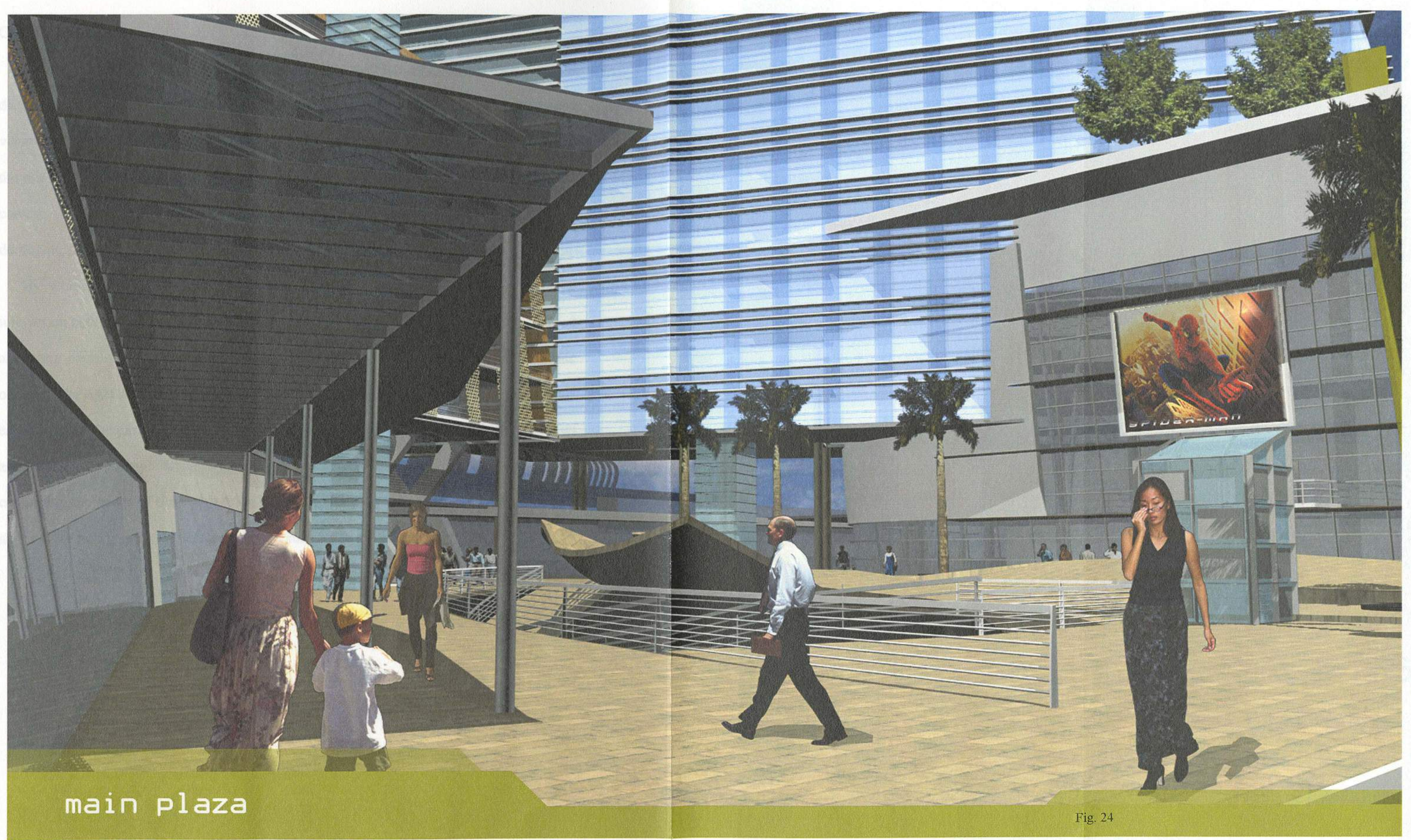




\section{Chapter 10. Summary}

It is a difficult task to have the car and pedestrians interact. People love their cars and they want to drive even to the store just around the corner. But they also want centers where they can walk without worrying about traffic or noise. In my design the car and the pedestrians interact in a positive way. My project provides spaces in which they can coexist. The pedestrians are provided zones where they can move easily when the car is dominant, and in the zones dominated by pedestrians the car is also present.

By working on this project, I have learnt there are techniques that can help the interaction between the car and pedestrian traffic, and that they can work together without alienating each other. For example, the main plaza opens to parking below to create openings for light and air, and creates visual connections with the car. This also creates easy access to the parking below. In the course of this project, I learnt to see the car as an asset not as an enemy. If we try to eliminate the car, we create isolated spaces. By combining the needs of both pedestrian and car traffic, we are able to serve the needs of all the users and create connections with the surrounding community. 


\section{REFERENCES}

Achimore, Alex. "Putting the Community Back into Community Retail." Urban Land August, 1993: 33.

Barnette, Jonathan. "Edge Cities to Real Cities." Planning Magazine November, 2002.

Bell, Jonathan. Carchitecture: When the Car and the City Collide. Berlin: Birkhauser Publishers, 2001.

Calthorpe, Peter and Fulton, William. The Regional City. Washington. DC: Island Press, 2001.

Chase, John, ed. et al. Everyday Urbanism. New York: Monacelli Press. 1999

Crawford, J. H. Carfree Cities. The Netherlands: Utrecht International Books, 2000.

Egan, Nancy. "Retail Roundup" Urban Land April, 2000: 68.

Fillip, Janice. "Uptown District, San Diego: Looking at the Future of Mixed-Use Development in American Cities." Urban Land June, 1990:2.

Fyfe, Nicholas, ed. Images of the Street. New York: Routledge, 1998.

Howe, Deborah., et al. "Beyond Strips and Centers: The Ideal Commercial Form." American Planning Association Journal Spring, 1992: 213.

Jennings, Jan, ed. Roadside America: The Automobile in Design and Culture. Iowa: Iowa State University Press, 1990.

Kaskin, Neisen. "Preserving a Sense of Place." Urban Land April, 2000.

Katz, Peter. The New Urbanism: Toward an Architecture of Community. New York: McGraw-Hills, 1994.

Kay, Jan Holtz. Asphalt Nation: How the Automobile Took Over America, and How We Can Take It Back. New York: Crown Publishers, 1997.

Lang, Robert. "The Store Next Door." Urban Land July 2000.

Leong, Sze Tsung. “...And Then There Was Shopping.” Harvard Design School 2001: 129.

Longstreth, Richard. City Center to Regional Mall: Architecture, the Automobile, and Retailing in Los Angeles, 1920-1950. Cambridge, MA: MIT Press, 1997. 
Lowe, Marcia. "Out of the Car, Into the Future." World Watch Nov/Dec. 1990: 20.

Lowe, Marcia. "Reclaiming Cities For People." World Watch July/Aug. 1992: 19.

McShane, Clay. Down the Asphalt Path: The Automobile and the American City. New York: Columbia University Press, 1994.

O’Toole, Randal. "Dense Thinkers.” Reason January, 1999.

Smiley, David, ed. Sprawl and Public Space: Redressing the Mall. New York: Princeton Architectural Press, 2002.

Stark, Judy. "Modern Village Goes Deeper Than Design." St. Petersburg Times February 19, 2000.

Untermann, Richard. "Streets Are For Sharing." Landscape Architecture July 1990: 55.

"Uptown District: San Diego, California" 8 Oct. $2003<$ http://www.gasthillmer.com/uptown.html>

Westlund, Richard. "Drive Time." Urban Land April 2000: 52. 